\title{
THE PRIVATE INVESTIGATOR AND THE RIGHT TO PRIVACY
}

\author{
ELAINE F. GEDDES*
}

\begin{abstract}
The author examines the law with respect to the status and powers of private investigators and reviews cases in both Canada and the United States involving the activities of private investigators. Passible remedies available against the private investigator, both in tort and criminal law, are reviewed, as well as American cases on the common law of invasion of privacy, Canadian cases under the various provincial Privacy Acts and possible remedies under the Charter of Rights.
\end{abstract}

Privacy is the right of the individual to decide for himself how much of his life, his thoughts, emotions and the facts that are personal to him he will share with others.'

\section{TABLE OF CONTENTS}

I. INTRODUCTION ...................... 256

II. THE PRIVATE INVESTIGATOR $\ldots \ldots \ldots \ldots \ldots \ldots \ldots \ldots, 259$

III. CRIMINAL LAW . ..................... 269

IV. PERSONAL INVESTIGATION LEGISLATION. ...... 271

A. TRESPASS ......................... 273

B. WILFUL INFLICTION OF NER VOUS SHOCK..... 274

C. NUISANCE .......................... 276

D. DEFAMATION ......................... 278

E. BREACH OF CONFIDENCE ............... 281

V. INVASION OF PRIVACY - THE AMERICAN CASES . . 284

VI. INVASION OF PRIVACY IN CANADA ........... 286

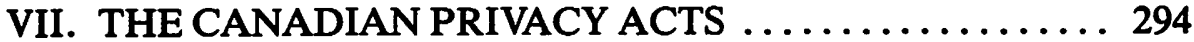

VIII. CONCLUSION ........................ 300

\section{INTRODUCTION}

Privacy is, for most people, a cherished concept. The right to retreat into the sanctity of one's own home and private life undisturbed by others is one most people would be outraged to discover had been violated. Most Canadians probably believe that they may not be followed, photographed, spied on, or reported on; nor may their personal lives, finances, history or occupations be investigated without their consent, or at the least, knowledge. Many would likely react with indignant protest if they were to be made the subject of such inquiries, and demand the inquiries cease. Most would be even more outraged to discover that in Canadian law there is no

- Visiting Assistant Professor, Faculty of Business, University of Alberta.

1. A Report to The Alberta Legislature of the Special Legislative Committee on Invasion of Privacy (Edmonton, 1969) 33. See also J. G. Fleming, The Law of Torts (7th Ed. 1987) 572. But see A. Schafer, "Privacy: A Philosophical Overview", in Aspects of Privacy Law (Gibson ed. 1980). 
real explicit recognition of a right of privacy per se. Those increasing numbers of Canadian jurisdictions that have passed a Privacy Act do recognize the right, but with exceptions and justifications that may provide an illusory level of protection. Personal investigation legislation provides for limitations on the types of inquiries that can be made in certain circumstances and the information that can be recorded. Both provincial telephone legislation and the Criminal Code prohibit wiretapping and electronic or other forms of eavesdropping. There still remains a large area, however, where the concern of the individual to prevent intrusions into his personal life is unmet by any statutory protection.

Recourse must then be had to the common law where protection of privacy interests is scattered among a variety of torts, and where the general right to privacy receives little judicial sanction. Cases have been confusing and contradictory. It has been stated time and again by courts that no general right to privacy exists at common law and yet a number of Canadian cases have raised and left open the possibility of a general common law action for invasion of privacy. One has actually come out and declared that such an action exists, ${ }^{2}$ but whether this case correctly states the law is open to some dispute. Other cases have protected some specific aspects of privacy under tort law, but how far these may be extended is uncertain. In any event, even where there is a recognition of a right to privacy, that right is not absolute. Where there are legal remedies against those who would interfere with a perceived right to privacy, they do not always provide the desired relief.

In an age of increasing concern about government intrusions into private lives, the primary fear of most people seems to be the large accumulation of information in government data banks, in police records, in intelligence and immigration files. The use of intelligence gathering techniques in the private sphere goes more or less unnoticed, save for the widespread concern with the activities of credit reporting agencies. Personal investigation legislation was drafted to meet that precise concern, but such concern focused not so much on deterring invasive techniques used to collect the information but rather on addressing the problem of inaccurate and damaging material on an individual's file.

Most people would tend to accept the duty and obligation of police officers to intrude into the personal lives of individuals suspected of offences, but few realize the extent to which other individuals do precisely the same thing in the course of carrying out their professions. One such individual is the private investigator.

In the public perception, private investigators or detectives occupy a grey area somewhere between police officers and ordinary citizens. There are few people outside the profession with any real idea of what they do, still less of what they are legally entitled to do. Even within the profession, there would appear from the cases to be some confusion over their legal status. Fictional work abounds on the private investigator from Sherlock Holmes to Benny Cooperman but serves no purpose (aside from obvious 
entertainment) except to confuse their status and activities. In reality, the work of the private investigator is much more mundane but, for that very reason, more likely to affect ordinary individuals than more celebrated exploits.

The range of services offered by a private investigator is very large. Many investigators specialize and hence build up considerable expertise in particular areas. Any area involving highly complex or technical matters tends to be an area of specialization such as arson investigation or commercial security. However, there are "general practitioners" as well who perform a variety of services for their clients.

Locating missing persons is a broad area, ranging from genuine "missing persons" cases to persons who are in hiding. Families may wish to locate a member who has gone missing, or next-of-kin who have simply fallen out of touch. More routine hunts could involve the search for heirs or next-of-kin for estate purposes, children who have been taken and hidden by a non-custodial parent, or witnesses required for civil or criminal proceedings. Defendants or judgment debtors in lawsuits may need to be located to receive service of documents. The recent upsurge in interest on the part of adopted or fostered children in tracing their natural parents or background has led to the involvement of investigators in this area. Investigators have also assisted in searching for blood relatives who might be able to provide transplants for victims of certain diseases.

Investigation of individuals may be done for a number of reasons. Such investigations may consist partly of surveillance and partly of information gathering. However, surveillance is often short-term and limited to certain types of cases, usually those involving bodily injury under insurance claims. Employers may request pre-employment checks, particularly where the prospective employment is of a sensitive or confidential nature. Employers may also request checks of existing employees where there is a suspicion of fraud, embezzlement or leaks of confidential material. Undercover work may be undertaken where an employer suspects theft or fraud in his place of business. Defendants and judgment debtors under a lawsuit may be investigated to determine the nature and location of their assets and property. Parties in domestic conflicts may hire private investigators to gather evidence for use in divorce or custody proceedings, to prove fault, or to show that one spouse is an unfit parent. Notwithstanding that adultery is not the important ground in divorce that it once was, adultery investigations are still quite common. Insurance companies frequently employ private investigators to investigate accident and injury claims as well as claims on fire and life insurance.

Some private investigators also offer security services. These might range from escort services for spouses exercising child visitation rights to "V.I.P." protection for visitors. Some engage in extensive security consultation work, working with businesses, in particular, to reduce theft and shop-lifting, or conducting security seminars for industry. They might offer protective services for witnesses or parties to lawsuits, or assist persons in the enforcement of injunctions or other court orders.

Routine investigations may involve a substantial amount of paperwork and searches through all available public records, including newspapers. 
An investigator will assist in searching for property liens and charges, company records, and court records and documents.

In the course of performing these varied tasks, investigators may make extensive investigation into an individual's private life, and even place that person under surveillance. In a routine insurance claim, there is usually only the most cursory of investigations, but where a fraudulent claim is suspected, an individual could be subject to prolonged investigation, including surveillance, questioning of family and friends, and other searching into one's personal background. Here the concern of the insurer to discover false or fraudulent claims may clash with the perceived right of the claimant to be free from intrusion into his personal life. There is a visceral reaction against many of the strategies adopted by investigators, and a feeling on many occasions that these strategies are simply unacceptable. This paper will attempt to deal with the privacy issues that may arise in the course of these investigations, and the possible legal remedies available against the over-zealous investigator.

\section{THE PRIVATE INVESTIGATOR}

Private investigators ${ }^{3}$ are governed by statute in all provinces, except Prince Edward Island, and are required to be licensed before they may carry out their profession. ${ }^{4}$ The provisions of these Acts apply equally to private investigators and to security personnel. This paper is confined to private investigators, and, although many comments will relate directly to security personnel, issues pertaining to that profession require separate treatment. In particular, the quasi-police function of some security guards, and their role in the protection of property give rise to issues that will not be dealt with here. ${ }^{5}$

The various acts tend to be similar in their definitions of a private investigator, although some are more detailed than others. Ontario's Act defines private investigator as follows: ${ }^{6}$

1.(d) "private investigator" means a person who investigates and furnishes information

for hire or reward, including a person who,

(i) searches for and furnishes information as to the personal character or actions of a

person, or the character or kind of business or occupation of a person,

(ii) searches for of fenders against the law, or

(iii) searches for missing persons or property.

3. All provinces require the use of the term "private investigator" and forbid the use of the term "private detective"; See, for example, Private Investigators and Security Guards Act, R.S.A. 1980, c. P-126, s. 20.

4. For the sake of convenience, the Alberta Private Investigators and Security Guards Act, supra, n. 4, has been used as the model in this paper and other Acts cited only where they differ in intent or detail. An excellent, although dated, comparison of the various Acts is found in P. Stenning and M. Cornish, The Legal Regulation and Control of Private Policing in Canada, (Centre of Criminology, University of Toronto, 1975). It is still of some value as many of the provisions have not been altered since 1975 .

5. For discussions of issues relating to security personnel, see: C.D. Shearing and P.C. Stenning, Private Security and Private Justice (The Institute for Research on Public Policy, Montreal, 1983); Private Policing and Security in Canada (Jeffries ed., Centre of Criminology, University of Toronto, 1973); and P. C. Stenning and C. D. Shearing, Search and Seizure Powers of Private Security Personnel (Law Reform Commission of Canada, 1979).

6. Private Investigators and Security Guards Act, R.S.O. 1980, c. 390, s. 1(d). A similar provision exists in the Manitoba Private Investigators and Security Guards Act, S.M. 1987, c. P-132, s. 1 . 
Specifically excluded from most definitions are peace officers, the R.C.M.P., barristers and solicitors, insurance adjusters, government employees, and persons who engage in credit or personal checks solely for the purpose of credit, bonds, insurance, financing or employment. All of these people may carry out somewhat analogous work but they are not engaged in investigation as their primary occupation.

Licencing requirements vary little across the country and are minimal in almost all jurisdictions. Most statutes require little more than that the applicant be over the age of majority and that the granting of the application be in the public interest. ${ }^{8}$ Regulations pursuant to most statutes are more specific, but the general requirements still refer mainly to the need for a good character and the absence of any criminal conviction for anything save minor of fences. There is a broad discretion in the granting of licences.

Most jurisdictions have no requirements for formal courses of study, training or examinations for investigators in order to obtain a licence, ${ }^{9}$ although many are in fact retired police officers or graduates of police science courses. The British Columbia and Newfoundland statutes are the exceptions. The B.C. statute requires applicants to provide information on their training, education, experience and skill, their mental condition, criminal record and any other information that might be relevant to their carrying on of the profession. ${ }^{10}$ Applications may be refused when any of these are held to be inadequate.

Newfoundland's statute and regulations are more extensive. Their Act provides that applicants must meet all prescribed qualifications including any required training programme. ${ }^{11}$ The regulations provide a detailed list of reasons for refusing a licence, or renewal of a licence. ${ }^{12}$ These include incompetence, financial instability, criminal convictions, unethical behaviour or other reasons where the public interest is adversely affected. There is a very wide discretion to refuse such applications. First time applicants for a licence must have passed a training course or examination approved by the province. ${ }^{13}$ Most other provinces would appear to be eager to have such regulations themselves, ${ }^{14}$ but legislative change to the various statutes does not appear to have a high priority. In the profession itself, there is a fear of stricter legislation being used to exert control over investigators to such a degree that they will become unable to protect the legitimate

7. See, for example, Man. Act, supra, n. 6, s. 30.

8. See, for example, Alta. Act, supra, n. 3, s. 7.

9. Ontario's Act provides that examinaitons may be required, supra, n. 6, s. 7(1).

10. Privte Investigators and Security Agencies Regulations B.C. Reg. 3/81, s. 2(1).

11. Private Investigations and Security Services Act, S. Nfld. 1981, c. 30, s. 15(1).

12. Private Investigations and Security Services Regulations Nfld. Reg. 227/81, s. 7.

13. Id. at s. 8.

14. See, Private Policing and Security in Canada, supra, n. S, and the comments therein of J.M. Ritchie, Director of Legal Services, Dept. of Solicitor General (Ontario), p. 13 et seq. , and R. M. Warren, Deputy Solicitor General (Ontario), p. 51 et seq. Also, private conversation with Ms. Gloria Ohrt of Dept. of Solicitor General (Alberta), Administrator of the Private Investigators and Security Guards Act, hereinafter referred to as Ohrt. 
interests of their clients. While more explicit licencing requirements might well meet with general approval, there is a concern that any overhaul of the legislation would include more substantive amendments as well, addressing imaginary fears and not real needs.

The existence of totally untrained investigators can be a serious problem to their colleagues, to the various government departments who administer the legislation, and to the general public. The untrained investigator is far more likely to run afoul of the law, and far more likely to close up his operations after a short time in business. He is also more likely to offer services to a client that he could not deliver, and in the end, more likely to give a bad impression to the public about the competence and ethics of the entire profession. Most complaints made to the Deputy Administrator of the Alberta Act are made about investigators who lack proper qualifications for their positions. ${ }^{15}$ Those complaints tend to centre around the investigator who fails to fulfil his promises to a client, or who loses documents, or who simply disappears leaving the Deputy Administrator to attempt to resolve the problems left behind.

The difficult task of defining qualifications for an occupation such as private investigator lies at the root of the problem. To narrow requirements to allow only for the licencing of those who have, for example, taken a particular prescribed course might be to disqualify some others with equivalent or even better qualifications. Some persons who could and do make excellent investigators have no specific training for the profession. They come from varied walks of life and bring particular types of expertise to their jobs. Notwithstanding that most investigators do have experience in police work of varying degrees, some discretion should remain to allow for the licencing of investigators whose qualifications are other than formal.

Administrators also seem to have a broad discretion over the suspension of licences. Licences may be suspended for criminal offences (in practice, only the more serious offences), failure to pay a judgement for damages, various regulatory offences or where the licence holder is felt to be unfit to hold the licence. ${ }^{16}$ The requirement that an investigator be a fit and proper person to hold a licence, and the provision that he may lose it for being unfit are both unsatisfactorily vague, but the problem is one of fashioning a better way to express the concept, while preserving some discretion to revoke or suspend licences. ${ }^{17}$ Investigators or the agency that employs them may be required to be bonded ${ }^{18}$ or give security ${ }^{19}$ and may be required to set up trust accounts for all money that passes through their hands. In Alberta, the amount of the fidelity bond required is currently $\$ 5,000.00$. Most private investigators carry liability insurance but are unable, at least

15. Ohrt, supra, n. 14.
16. See, for example, Alta. Act, supra, n. 3, s.9.
17. Ohrt, supra n. 14 .
18. See, for example, Man. Act, supra, n. 6, s. 7.
19. See, for example, Alta. Act, supra, n. 3, s. 6. 
in Canada, to get errors and omissions insurance. In the insurance field, this can lead to some nervousness as an error on the part of an investigator with respect to an insurance claim might leave him open to a claim by the insurer which could be quite disastrous. Independent claims adjusters, often doing similar work, are able to get errors and omissions insurance; so the lack of availability of this type of insurance for the investigator seems regrettable. There does not appear to be much cause for concern over the inherent untrustworthiness of investigators, since, in the last thirteen years, there has only been one claim against the security of an Alberta private investigator. ${ }^{20}$

Private investigators are forbidden under the Alberta Act to wear uniforms or any badge or insignia, or to do or say anything which could conceivably cause confusion as to their status. ${ }^{21}$ They are also prohibited in Alberta from holding themselves out as police officers or as capable of performing the duties of police officers. ${ }^{2}$ They are prohibited from acting as debt collectors. ${ }^{23}$ In many jurisdictions there is a specific ban on the carrying of firearms. ${ }^{24}$ Alberta regulations provide that a private investigator may receive a licence to carry a restricted weapon if approved by a senior police officer in the jurisdiction and the local Registrar of firearms, where the licence is necessary for the carrying out of a specific duty. ${ }^{25}$ Investigators have applied, but no such licence has ever been granted. ${ }^{26}$ The position of the Deputy Administrator on this point is that the issuance of firearms is almost never required and the reasons given by most applicants are spurious. It would be dangerous to begin to allow such permits as the arming of private investigators is not desirable from a policy point of view. ${ }^{27}$ (Although the Deputy Administrator is not in fact a person whose approval is required, in practice she is always consulted.) $)^{23}$ Some of the desire to carry weapons can be attributed to a number of American investigators who have set up in Canada, or American agencies that have branch offices here. Rules in the United States dealing with the possession of weapons are more lenient and some of these investigators believe it to be their right to carry weapons. ${ }^{29}$

Some provinces have a requirement of confidentiality for information obtained in the course of an investigation. The Alberta Act provides that: ${ }^{30}$

Except as legally authorized or required, a person who holds or has held a license under this Act shall not divulge to anyone, any information acquired by him in the course of the business or employment in respect of which the license is or was held.

20. Ohrt, supra $\mathrm{n}$. 14. In the past year, three claims have been made but they have not yet been processed. All involved investigators who went out of business.

21. Supra, n. 3, s. 19.

22. Id. at s. 17. The identification card that private investigators are required to carry has a phrase that states: "This card does not give the holder the authority of a peace officer:"

23. Id. at s. 16.

24. See, for example, Private Investigators and Security Agencies Act, S.B.C. 1980, c. 45, s. 21(1); Newfoundland Act, supra, n. 11, s. 36.

25. Alta. Reg. 188/73, s. 32.1(2).

26. Ohrt, supra n. 14.

27. Id.

28. Id.

29. Id.

30. Supra, n. 3, s. 15. 
Most investigators are capable of extra-provincial investigations. Most provincial legislation specifically provides that out-of-province investigators do not need to obtain licences for the purpose of a specific investigation in that province. ${ }^{31}$ However, where an out-of-province investigator wishes to undertake an investigation in Alberta, for example, he is required to notify the local police in advance of his arrival, stating when he will be arriving, for what purpose, and for how long he anticipates being in the province. Once his specific investigation is over, he is required to leave..$^{32}$ In the event that an investigator will not make an extraprovincial investigation himself, he is usually in the position of being able to refer a client to an investigator in the other province. Many have contacts in other countries as well for referral purposes.

There are 157 licenced agencies in Alberta under The Private Investigators and Security Guards Act. ${ }^{33}$ This includes agencies which are solely private investigators, those which are solely security guards, and those who combine both services. There are no figures which break down the licences between investigators and security guards. Indeed some individuals hold licences as both. There are private investigators in nearly every Alberta city. Most are local individuals or firms, although many are offices of larger provincial, interprovincial or, in a very few cases, international firms.

It appears to be well settled that a private investigator has no more power in the carrying out of his activities than any ordinary citizen. ${ }^{34}$ This point is not, however, reflected in the legislation, which appears to be more concerned with regulatory matters than with the legal status of the investigator. In New Zealand, however, the statute regulating the profession includes a section dealing specifically with the lack of any special powers for investigators: ${ }^{35}$

No person shall, by virtue of being the holder of a license or certificate of approval, have any power or authority that he would not have if this Act had not been passed.

Canadian cases have on occasion been required to deal with the question of the status of the investigator and have on all such occasions firmly declined to allow any greater powers of investigation than are possessed by the ordinary citizen. In $R$. v. Andsten ${ }^{36}$ the defendant private investigators

31. See, for example, Alberta Act, supra, n. 3, s. 3(3) in Alberta, no out-of-province private investigator can commence an investigation in Alberta, but may enter only for the purpose of some limited aspect of an investigation.

32. Information obtained verbally from the Office of the Alberta Department of Solicitor General.

33. Id. This figure was as of December 1987. The numbers vary from 140 to 160 in recent years.

34. This point of view has been criticized as too simplistic: see, Shearing and Stenning, 1983, supra n. 5 at 19. But the reference there is to security guards acting in their role as agents for property owners. Much of their discussion involves security personnel in their quasi-police function, which is outside the scope of this paper.

35. Private Investigators and Security Guards Act, S.N.Z. 1974, no. 48, s. 66(1).

36. (1960) 32 W.W.R. 329. 
appealed a conviction under s. 162 (now s. 177) of the Criminal Code on the grounds, inter alia, that they lacked the necessary mens rea: ${ }^{37}$

\begin{abstract}
That submission is based upon the evidence that the appellants believed from the custom long followed by private detectives that they had the right to enter private property and remain thereon in order to carry out a lawful investigation. . . . their mistake was one of law not of fact; they did not know that sec. 162 made their actions a crime. The mens rea lies in the fact that the appellants deliberately did those things that sec. 162 forbids. Their ignorance of that section and their belief that they were acting legally do not rebut mens rea or provide a defence.
\end{abstract}

It was also argued in that case that the defendants had a lawful excuse for their behaviour, on the ground that a lawful excuse needed only to be a reasonable explanation that involved nothing illegal. The defendants were retained by a husband to search for evidence of adultery on the part of his estranged wife. Davey J.A., in delivering the judgment of the Saskatchewan Court of Appeal, disagreed with this definition of lawful: $:^{38}$

... "lawful" means just what it says; the excuse must be one that is lawful under the law of the land; ... The explanation that the appellants were investigating the wife's conduct does not excuse or justify the trespass committed by their invasion of her property, and so cannot be a lawful excuse under sec. 162 for loitering thereon.

This was cited with approval by Walker D.C.J. in R. v. Gibson ${ }^{39}$ another Saskatchewan case. There a private investigator was charged with a violation of s. 307(1) (now s. 349(1)) of the Criminal Code (entering a dwelling house with intent to commit an indictable offence). The issues in both cases were identical with respect to the right alleged by the investigators. In both cases the investigator seemed to have the mistaken belief that "his license, employment and mission made his actions proper"..$^{40}$ It would appear that the defendants believed that, as private investigators, they had the right to pursue their investigations wherever those investigations took them, even to the extent of loitering around a house at night or entering a house under a misrepresentation. However, in $R$. v. Massue ${ }^{41}$ the defendant private investigator conceded that an entry into an apartment for the purpose of obtaining evidence of adultery was without lawful excuse. This case also involved a charge of entering a dwelling house with intent to commit an indictable offence, this time in Québec. It would appear to be decided that, at least as far as offences under the criminal law are concerned, no colour of right can attach to otherwise unlawful behaviour by private investigators.

In Schultz v. Frankfort Marine Accident and Plate Glass Insurance Company ${ }^{2}$ an American court held that private investigators who claimed to be collecting evidence for a possible perjury conviction could not use that to excuse unlawful behaviour: ${ }^{43}$

The defendants are not public officers. So far as the enforcement of the criminal laws are concerned, they have no duties except those common to all private citizens.

37. Id. at 332.

38. Id. at 331.

39. [1976] 6 W.W.R. 484.

40. Id. at 490.

41. [1966] 3 C.C.C. 9.

42. (1913) 139 N.W. 386 (Wisc. Sup. Ct.).

43. Id. at 390-391. 
Other American cases have repeatedly made the same point as to the lack of any special powers or rights for private investigators. ${ }^{44}$

In Poznanski v. Stosic, ${ }^{45}$ an Austrialian court held that private investigators entering a dwelling house to search for evidence were there without lawful excuse, and judicial disapproval of such behaviour was expressed:46

... entries of that kind are liable to lead to breaches of the peace and I do not think that the courts should countenance them. Even a police officer in search of crime is not allowed to enter a private dwelling without the occupier's consent unless under a search warrant or under the provision of a statute giving him authority to do so.

It is to be noted here that the Australian court points out how illogical it would be to allow a private investigator greater rights of investigation than those given to police officers.

In Davis v. McArthur, ${ }^{47}$ an action under the British Columbia Privacy Act, ${ }^{48}$ Tysoe J.A. dealt with the possibility that the defendant might have a defence to a claim of invasion of privacy under s. 2(1) (now s. 1(1)) or s. $3(1)$ (c) (now s. 2(1)(c)). Section 1 creates the tort of invasion of privacy where another's privacy is violated without claim of right. Section 2(1)(c) provides that an act is not a violation of privacy if done under authorization by some law. Tysoe J.A. agreed with the trial judge that the appellant's "role as private investigator does not give a claim of right ... or authorization ... . so as to afford a complete defence . .". ${ }^{49}$ In that case, the issues were somewhat different than the cases involving criminal charges, but the key point to be noted is that the private investigator is again characterized as having no general powers of investigation, and no legal rights, over and above those possessed by the ordinary person.

None the less, while the legal rights of an investigator are no more extensive than those of the ordinary person, it by no means follows that "his position as a private investigator is not relevant"..$^{30}$ There is an acceptance that a private investigator may and often does have a legitimate interest recognized by law in carrying out his investigation. It seems that he stands in the position of agent with respect to his client and if the client's interest is recognized as legitimate, the investigator's interest is likewise legitimate. In Davis v. McArthur ${ }^{\text {s1 }}$ this was one of the crucial factors exonerating the investigator, given that the B.C. Privacy Act requires due regard to be given to the lawful interests of others, and to the nature of any relations between the parties: $:^{52}$

The appellant was acting as the agent of the wife who had a legitimate interest in her husband's conduct. He was not activated by malice or mere curiosity.

44. North Carolina Association of Licensed Detectives v. Morgan (1973) 195 S.E. 2d 357 (Ct. App.); McLain v. Boise Cascade Corp. (1975) 533 P. 2d 343 (Ore. Sup. Ct.); People v. Zelinski (1979) 594 P. 2d 1000, (Calif. Sup. Ct.).

45. [1953] S.A.S.R. 132.

46. Id. at 139-40. Cited with approval in $R$. v. Gibson, supra, n. 39, at 485-86.

47. [1971] 2 W.W.R. 142 (B.C.C.A.).

48. R.S.B.C. 1979 , c. 336 .

49. Supra, n. 47 at 146.

50. Id. at 147.

51. Supra, n. 47.

52. Id. at 147. 
In Insurance Corporation of British Columbia v. Somosh and Somosh, ${ }^{53}$ another action under the B.C. Privacy Act, the plaintiff corporation was held liable for the actions of the investigator it had hired. In that case, the investigator had made inquiries about both of the defendants with a view to enforcing a possible judgment against them. However, Cashman L.J.S.C. held that: ${ }^{54}$

... there never was a cause of action against Mr. Somosh.

The plaintiff corporation had no business hiring an investigator to make any investigation of Mr. Somosh.

The judge continued:ss

The plaintiff had no legitimate interest in the personal habits of Mr. Somosh and in fact had no claim against him arising out of the accident.

It can be seen, therefore, that when the client has no legitimate interest in the investigation, the investigator loses whatever protection legitimate interest gave him. Thus it would appear that a frivolous or vexatious investigation could cause an investigator to have greater liability than where there is a legitimate interest.

It must be pointed out that while investigators have no more powers than ordinary citizens to carry out investigations, the investigator has the advantage of, for example, having ties to a local police department that an ordinary citizen does not have, and the police frequently will assist in providing information. Police may also assist in obtaining search warrants and carrying out those searches for the investigator in the appropriate case.

In the United States, and arguably in Canada as well, a plaintiff who files a personal injury claim must expect to have the claim investigated: $:^{56}$

Courts have recognized that there is social utility in these investigations because it is in the best interests of society that personal injury claims be valid and that fraudulent claims be exposed. A plaintiff's right to privacy is therefore waived to some extent when he makes a claim, because a defendant's insurer has a right to make a reasonable inquiry and investigation into the validity of the claim.

This position by the American courts has been fiercely attacked on occasion, ${ }^{37}$ but it is probably too firmly backed by judicial authority to be overturned now. Even plaintiffs' lawyers reluctantly accept that investigation of the plaintiff's claim is a fact of life which they must live with.

No Canadian case has directly addressed the issue of the right of an insurer to make such an investigation, doubtless because a common law right to privacy does not exist in Canada as it does in the U.S. The reasoning of American courts, however, would doubtless recommend itself to Canadian courts should such an issue arise, possibly under one of the Privacy Acts.

53. (1983) 51 B.C.L.R. 344 (B.C.S.C.).

54. Id. at 353 .

55. Id. at 355 .

56. G. LaMarca, "Overintrusive Surveillance of Plaintiffs in Personal Injury Cases", (1986) 35 Defence $L . J ., 603$ at 604 . This point was most forcefully made in Forster v. Manchester (1963) 189 A. 2d 147 at 150 (Penn. Sup. Ct.).

57. See M. F. Mayer, Rights of Privacy (1972), wherein he refers to Forster (supra, n. 56) as a "strange" decision which "must be rejected" (at 13). But see also LaMarca, supra, n. 56 where the permanence of the doctrine is accepted. 
The courts in Davis v. McArthur ${ }^{58}$ recognized the right of a private investigator to investigate in divorce cases based on the legitimacy of interest of the spouse who has hired them. Spouses have a legitimate interest in the extra-marital activity of their husbands or wives, and by extension, this would probably apply in cases of custody or maintenance disputes. No cases touch directly on the question of surveillance or investigation of possible criminal offences, but where the client is an employer or other person with a direct interest in such an investigation, this would in all likelihood be considered legitimate interest.

But even where there is legitimate interest, many of the activities of the private investigator may cause a great deal of distress to the subject under investigation. In the United States, unreasonable surveillance activity may make the investigator liable to the subject in tort. Both secretive and open surveillance have been held actionable. ${ }^{99}$ The key is always the reasonableness of the action.

In an instructive American article prepared for use by plaintiffs' lawyers in personal injury cases, George LaMarca outlines some of the more offensive methods used by investigators to test the legitimacy of a plaintiff's claim. ${ }^{60}$ These include duping the plaintiff to engage in physical activities which he or she might not be capable of, offering the plaintiff a job involving physical exertion, intentionally flattening a tire and observing the plaintiff's attempts to change it, leaving something to obstruct the plaintiff's driveway or sidewalk and observing plaintiff's attempts to remove it. In all cases, the investigator would film the activities for use as evidence of the degree of physical impairment. LaMarca points out that the problem with the use of surveillance film is that it is not as accurate as it purports to be. A film may show a man digging in his garden but it cannot show the pain and discomfort he may have felt while doing it, nor will it show how he may have felt the next day after his over-optimistic efforts. Unlike testimony given in court, the "testimony" of a film or photograph is not so easily explained. ${ }^{61}$ On the other hand, one-time surveillance is not always acceptable to an investigator or insurer either, for precisely the same reasons. A photograph cannot show impaired movement, while a videotape can. But one videotape cannot necessarily prove the extent of injury or impairment if that videotape was taken on a non-representative day. A subject may have dug his garden one day and the videotape may show this. If that is the evidence the insurer takes into court, he may hear in re-direct that the subject spent the next two days in the hospital recuperating. The value of the tape as evidence would thus be highly questionable.

In order to be satisfactory evidence, a surveillance must take place over a longer period of time. A single act of surveillance can, however, be useful in those cases where the plaintiff claims that his injuries are so severe that

58. Supra, n. 47.

59. See, for example, Souder v. Pendleton Detectives Inc. (1956) 88 So. 2 d. 716 (La. Ct. App.); and Schultz, supra, n. 43.

60. LaMarca, supra n. 56, at 608-11.

61. Id. 615,619 . 
he cannot work at all. He would then certainly have some explaining to do when faced with a photograph showing him playing hockey.

LaMarca also points out that there are many reasons for a plaintiff's attempt to perform certain activities. ${ }^{62}$

Such attempts to resume a normal life cannot be abstractly categorized as evidence of fakery.

Ironically, such surveillance often penalizes the non-malingering plaintiff who attempts to return to a normal life as quickly as possible but may have misjudged her physical ability at the particular time or who, despite an actual disability, simply performed an activity out of frustration, ego dynamics, or social pressure.

An investigator therefore must have enough material in an activity report to show the context in which a certain activity was performed, in order for the activity to be of probative value.

Canadian private investigators ${ }^{63}$ are less likely to participate in some of the more dubious activities outlined above, but they do keep subjects under covert surveillance as a routine matter in some types of cases. An investigator acts under instructions from his client, and these instructions can vary widely. The investigation may be given free rein by a client to do whatever he feels necessary to obtain information, subject only to his own concerns over legality and ethics. Or he may be placed under quite severe restrictions as to how much contact with the subject he will be allowed, and what kinds of activities he will be permitted to undertake. However, the arsenal of weapons available to investigators is quite large: filming or photographing subjects in public places or when on private property open to the public gaze; filing activity reports detailing a subject's daily activities - where he goes, what he does, whom he sees; questioning neighbours, friends and co-workers, often without revealing their interest in the subject; searching public records, such as home ownership, vehicle registrations, and court records; misrepresenting themselves to the subject or anyone else in order to gather information - such as pretending to be canvassers or taking a survey in order to make a closer assessment of the subject. ${ }^{64}$ Most private investigators accept these investigative tools as matters of routine and as necessary for obtaining a proper report. In all likelihood, these activities should not raise concerns if undertaken for a legitimate purpose and done discreetly.

But there are restraints which operate on an investigator, most of them of his or her own making. The ethical investigator sees himself or herself as a gatherer of information or intelligence. He or she does not "make things happen" in the sense of creating a situation to which the subject is required or expected to respond. In the investigation of a personal injury case, an investigator might strike up an acquaintance with a subject in a club. She may sit down and introduce herself and talk with him, but she will not ask or encourage him to dance. If he suggests it, this would be a different

62. Id. p. 619 .

63. I am indebted to Messrs. Dennis Shepp and Bill Johnman of Shepp, Johnman and Associates, Private Investigators in the city of Edmonton, for much of the information in the following paragraphs. Any errors are, obviously, mine.

64. Id. 
matter as he has initiated the action, and the investigator would then be merely responding and observing his physical capabilities. But to place the idea in his head herself would be to "make something happen", to create a scenario, rather than insinuate herself into a presently existing one. Thus, many of the worst excesses seen in some of the American cases are avoided. There are voluntary ethical standards to which many investigators adhere. For most reputable investigators, the primary concern is their own reputation and their credibility. It is crucial to them to be known as individuals who are able to provide good usable evidence. There is no point to amassing a body of information that has no value in court. There can be a real fear of illegal behaviour which could cause the loss of a licence, not ony for the individual investigator, but for the entire firm. However, there are a small minority in the profession who would not hesitate to go beyond the bounds of what is considered legal or ethical behaviour, such as the anonymous investigator who appeared before a legislative committee of the Alberta Legislature in 1969: $:^{65}$

You never get caught. That is the difference between a good investigator and a bad one, isn't it? If you're going to get caught, you might as well not be an investigator. Whether you're doing something right or wrong, the whole idea is not to get caught.

Fortunately, a genuinely criminal frame of mind such as was displayed by this individual is rare.

On some occasions, the instructing client can encourage wrong-doing. If he does so he must accept the consequences, particularly where the client is a lawyer or an insurance company who is well aware of the legal and ethical restrictions which ought to operate. Often evidence obtained in this fashion is never meant to be used in court, which accounts for the lack of concern for its probity. Its value is "coercive" only. Investigators will often refuse to accept assignments where the instructions quite clearly indicate that the client's concern is not a completely legitimate one.

Even the most ethical and unobtrusive of investigators can cause much grievance to a subject under investigation. Those investigators who are not quite so ethical and unobtrusive can cause substantially more. To what extent do present remedies in Canadian law protect against the intrusions of the private investigator? To answer this, one must have recourse to a number of different areas of tort, criminal and statute law.

\section{CRIMINAL LAW}

We have seen that a private investigator enjoys no greater legal rights in the carrying out of his investigations than any private citizen. Thus, they have no greater powers of arrest, or of search and seizure. As discussed earlier, ${ }^{60}$ the court in Gibson ${ }^{67}$ did not accept that the accused's profession as a private investigator gave him any lawful excuse for what was essentially trespass. Furthermore, it is specifically stated in s. 350(b) of the

65. Supra n. 1, at 22.

66. See p. 00.

67. Supra, n. 39. 
Criminal Code ${ }^{68}$ that a person is deemed to have broken and entered if he obtained entry by way of artifice, as was the case there. In Massue, ${ }^{69}$ the lack of lawful excuse was conceded, but the defendent argued lack of intent to commit an indictable offence. The court found that resisting the attempts of the occupants to remove him from the property constituted assault.

In Andsten, two investigators were charged with a violation of s. 177 (then s. 162) of the Criminal Code, trespassing at night. ${ }^{70}$ That section also requires the accused to provide lawful justification or excuse for his presence. Again the court refused to accept that a private investigator has, in the normal course of events, a lawful excuse for trespass. They also rejected the rather fanciful argument that the two men were not loitering as they were working and busy at the time."

A possible charge against an investigator could be laid under s. 423 of the Criminal Code, dealing with intimidation. That section provides that:

423. (1) Every one who, wrongfully and without lawful authority, for the purpose of compelling another person to abstain from doing anything that he has a lawful right to do, or to do anything that he has a lawful right to abstain from doing ...

(c) persistently follows that person about ...

(f) besets or watches the dwelling-house or place where that person resides, works, carries on business, or happens to be ...

is guilty of an offence punishable on summary conviction.

It is conceivable that the actions of some investigators may be perceived by the subject as constituting attempted intimidation. It would certainly come to mind as the possible outcome of a domestic dispute where a separated spouse was being watched for evidence of adultery. There would appear to be no cases on this point. However, s. 423(2) provides a defence: a person who approaches a dwelling house for the sole purpose of obtaining information is not guilty of an offence. Therefore, an investigator who confined himself to the gathering of information would not be in danger of a charge of intimidation.

Another possible charge could be that of mischief under s. 430 of the Criminal Code. That section reads:

430 (1) Every one commits mischief who wilfully

(a) destroys or damages property,

(b) renders property dangerous, useless, inoperative or ineffective,

(c) obstructs, interrupts or interferes with the lawful use, enjoyment or operation of property, or

(d) obstructs, interrupts or interferes with any person in the lawful use, enjoyment or operation of property.

The private investigator who "makes things happen", who deflates car tires, smears windows, leaves objects in the driveway, moves things about or removes objects from property could certainly be faced with a charge under this section. However, there is also a defence to a charge of mischief under s. 430(7) of the Code: approaching a dwelling house, or attending

68. R.S.C. 1985 , c. C-42.

69. Supra, n. 41.

70. Supra, n. 36.

71. Id. at 331 . 
nearby solely to communicate or obtain information is not mischief. Again, the investigator who confines himself to the gathering of information is not guilty of an offence.

There is no offence either under the Criminal Code or under the common law of being either an eavesdropper or a "peeping tom". ${ }^{2}$

Electronic surveillance is outlawed under s. 183 et seq. of the Criminal Code, unless the interception is authorized or unless consent is given. This applies only to the interception of communications, so it would probably not cover the planting of locator devices, or "bumper beepers" as in Davis v. McArthur. ${ }^{73}$ The consent issue is, however, of greater importance, as frequently conversations would be monitored at the request of the client who would be one of the parties to the conversation. Section 184(2) exempts communications where the originator or recipient of the communication has given consent for its interception. This could easily be done without the other party being aware that such interception is taking place. Evidence obtained in such a fashion is admissible under s. 189(1)(b).

Possession of equipment capable of intercepting communications is an offence under s. 191. A private investigator must not possess such equipment unless he holds a licence from the Solicitor-General (s. 191(2)(d)). This section refers to equipment primarily for use in intercepting communications; however, most of this equipment has numerous legitimate purposes as well, so prosecuting a charge could prove difficult.

Various provincial statutes also prohibit the attachment of any recording or transmitting devices to any telecommunications equipment without approval..$^{74}$ The interception of or listening to telecommunications without authority is forbidden and can lead to a jail sentence.

Criminal sanctions are useful to those under surveillance only to the extent that a criminal charge may effectively end the surveillance or interference by the investigator. A criminal conviction could mean the loss of an investigator's licence. It does not compensate, however, for any damages suffered by the individual in the course of the investigation, with the exception that s. 194 does provide for punitive damages of up to $\$ 5,000.00$ to be paid to a person where an accused has violated his rights by way of an unauthorized interception. Furthermore, where one investigator has been charged, it does not necessarily follow that another will not be sent to take his place, and the problem could continue unabated.

\section{PERSONAL INVESTIGATION LEGISLATION}

Statutes providing for the fair investigation and reporting of personal credit's are unlikely to assist to any great extent in protecting oneself from the inquiries of a private investigator. Alberta does not possess such a

72. The King v. County of London Quarter Sessions Appeal Committee [1948] 1 K.B. 670 (C.A.); Frey v. Fedoruk and Stone [1950] S.C.R. 517.

73. Supra, n. 47.

74. See, for example, Alberta Government Telephones Act, R.S.A. 1980, c. A-23, ss. $29,31$.

75. See, for example, Personal Investigations Act, R.S.M. 1987, c. P34; Credit Reporting Act, R.S.B.C. 1979 , c. 78. 
statute, but in those provinces that do, the control over the gathering of information is limited to certain specific purposes. The Uniform Law Conference Of Canada's Model Act ${ }^{76}$ lists, for example, six purposes:

1. The extension of credit or the collection of a debt;

2. The entering into or renewal of a tenancy agreement;

3. Employment by or of the person;

4. Underwriting of insurance involving the person;

5. Eligibility, or any matter under a statute, regulation or bylaw;

6. A direct business transaction involving the person.

Some statutes are even more restrictive than this. ${ }^{n}$ Private investigators are engaged primarily in activities outside the scope of these purposes. The Acts of Alberta, Ontario and Manitoba, governing investigators, specifically exclude from the definition of investigator people who furnish credit information. ${ }^{78}$ It would be rare for an investigator to investigate prospective tenants, applicants for insurance or a person's eligibility under any statute. Employment checks are usually done after employment has commenced, where there is some suspicion of wrongdoing. It is submitted that the phrase "employment by or of the person" in the Model Act" does not include investigations of a person subsequent to the obtaining of employment. Only pre-employment checks would be included under the statute and then the investigator would probably be required to abide by its terms. The compiling of certain types of information would then be prohibited. Many elements of what is sometimes referred to by investigators as a "lifestyle report" might run afoul of the Model Act in that it can include personal information on spending habits, social life, acquaintances and personal morality. Provided that the employer can justify the obtaining of such information on the grounds of the sensitive nature of the employment situation, and provided also that the information is properly attributed and corroborated by the investigator, even these intimate details may be permitted by the statutes. What exactly is covered by "a direct business transaction" in the Model Act is unclear, but would probably not include most of the matters dealt with by private investigators.

Even if a private investigator occasionally engaged in the activities covered by the various acts, that might not be sufficient to make him a reporter or a reporting agency within the meaning of those acts, and so the prohibitions on furnishing reports would not apply. If an investigator were to obtain information from a credit reporting agency for a purpose other than those authorized by the act he might then be guilty of an offence. ${ }^{\text {so }}$ Otherwise, it is quite possible that the acts would have no application to private investigators at all in the normal course of their business. Dale

76. Uniform Information Reporting Act, Uniform Acts of the Uniform Law Conference of Canada (1977) 23.

77. See, for example, Manitoba's Act which restricts application to investigations for credit, insurance, employment and tenancy, supra $\mathrm{n} .75, \mathrm{~s} .1$.

78. Supra, n. 3 and n. 6.

79. Supra, n. 76.

80. See, for example, B.C. Act, supra, n. 24, s. 10. 
Gibson, perhaps recognizing that the activities of private investigators are not ones which can be appropriately dealt with by these acts, has suggested that perhaps they not be included, provided that there is adequate legislation protecting the subjects of their investigations. ${ }^{81}$ As we have seen, however, such legislation is non-existent in Canada.

\section{A. TRESPASS}

Where there has been actual physical intrusion onto the plaintiff's property, an action will certainly lie in trespass. Trespass remains actionable without proof of damage so no actual injury is necessary for the plaintiff to be successful..$^{22}$ The trespass can be committed surreptitiously, without the subject's knowledge, or openly, as where an investigator refuses to leave ${ }^{83}$ or it may be committed as the result of a misrepresentation. ${ }^{84}$ In all cases, the investigator is on private property with no lawful justification for his presence.

An investigator who approaches a house in the normal manner in daylight hours is probably not trespassing until or unless he is asked to leave. But night surveillance, loitering or eavesdropping are different matters altogether. ${ }^{85}$ Entering a dwelling house without permission is the most hazardous and likely to lead to liability. Unlawful entry is trespass whether done surreptitiously or through guile: 86

Surely permission to enter obtained by misrepresentation is no permission at all. . . . a person is deemed to have trespassed if he obtained entrance by artifice or pretext.

These cases of actual entry or of active investigation on the property itself seem to have been dealt with in this country mainly under the criminal law (see preceding section).

One crucial problem in this area is that an investigator who enters a person's house under a misrepresentation, having received permission to enter by the lawful occupant, may be liable for trespass on the grounds that permission to enter was given for a specific purpose, which was not the actual purpose of the investigator. ${ }^{87}$ If the investigator identifies himself, then the subject cannot be heard to complain. But if the investigator indicates that he is, for example, taking a survey, and under that guise spends some time speaking with the subject in order to obtain a closer assessment of him, this could be characterized as trespass for which the investigator will be liable in the absence of any damage. This interview technique is one which is not uncommonly used in order to assess persons making bodily injury claims. Investigators are frequently successful in getting such innocent individual to reveal substantial amounts of material about themselves.

81. D. Gibson, "Regulating the Personal Reporting Industry" in Aspects of Privacy Law (D. Gibson, ed., 1980) 111.

82. See Fleming, supra, n. 1, at 37.

83. R. v. Andsten, supra, n. 36.

84. R. v. Gibson, supra, n. 39.

85. R. v. Andsten, supra, n. 36.

86. R. v. Gibson, supra, n. 33.

87. See Fleming, supra n. 1, at 39. 
Mere technical trespasses may not be considered to be trespass by the court. In Belzberg v. BCTV Broadcasting System Ltd. ${ }^{88}$ television reporters who stepped on the plaintiff's property momentarily were held not to have trespassed although they were filming the plaintiff's house. In Silber v. B.C.T.V., ${ }^{89}$ the defendants were found liable for trespass onto the plaintiff's parking lot, but the damage was held to be nominal and the award was only $\$ 100.00$. It can be argued that television reporters and private investigators have somewhat analogous professions, and therefore, the mere stepping onto a plaintiff's property would, at best, result in only nominal damages.

However, courts have jurisdiction to award larger amounts of money as punitive or as exemplary damages in the appropriate case. A trespass which involved quite offensive behaviour could be adequately compensated for. At least one Australian case has awarded damages for hurt feelings arising out of a trespass. ${ }^{\circ 0}$

Trespass can also occur to chattels, so interfering with a plaintiff's car or any other of his possessions is also a tort. Flattening a tire or moving objects around in order to observe the subject moving them back again would be examples of such trespass, as would examining letters or other documents.

However, most investigators do not actually enter onto a plaintiff's land. Reputable investigators also avoid setting up a subject or "making things happen". They usually conduct their investigations at some distance; therefore, the tort of trespass will be of little assistance.

\section{B. WILFUL INFLICTION OF NERVOUS SHOCK}

The more outrageous behaviour of an investigator may be compensated for under the principles first laid down in Wilkinson v. Downton. ${ }^{91}$ In that case, Wright J. permitted recovery where a woman was falsely told that her husband had been severely injured. The court held the defendant liable on the grounds that he should, as a reasonable man, have known that the effect of his words would be to inflict physical harm through emotional distress. The case established a cause of action for wilful conduct which is calculated to cause and does cause such harm. An investigator may be liable if the surveillance activity is such that it causes emotional distress in the absence of legal justification.

The case of Janvier v. Sweeney ${ }^{92}$ followed Wilkinson in affirming that a right of action exists where: ${ }^{93}$

... the defendant has ... wilfully done an act calculated to cause physical harm to the plaintiff - that is to say, to infringe her legal right to personal safety, and has in fact thereby caused physical harm to her.

88. Belzberg v. British Columbia Television Broadcasting System Ltd. (1981) 3 W.W.R. 85.

89. (1986) 69 B.C.L.R. 34.

90. Greig v. Greig [1966] V.R. 376 (Sup. Ct.).

91. [1897] 2 Q.B. 57.

92. [1919] 2 K.B. 316.

93. Id. at 322 . 
In that case, the plaintiff was employed by a lady in whose house she resided. The defendants were private investigators in the employ of one Major X, who wished to lay his hands on some letters in the possession of the plaintiff's employer. The year was 1917. One of the defendants called at the house and told the plaintiff that he represented the military authorities and that they wanted to question her as she was corresponding with a German spy. The plaintiff was a Frenchwoman who was in fact engaged to a German who was under internment in the Isle of Man. The accusation caused the plaintiff to suffer severe shock and there was medical evidence that she became extremely ill. The Court of Appeal found it appalling that the defendants would resort to such measures to induce the plaintiff to cooperate in obtaining the letters, and damages were awarded against the defendants.

In the early American case of Schultz, ${ }^{94}$ the defendants were sued for conspiracy to intimidate the plaintiff into leaving town and preventing him from testifying as a witness. The defendant detectives behaved in an altogether outrageous manner: following the plaintiff and threatening him with violence; kidnapping and prosecution; eavesdropping; entering his house; lying about him to his neighbours; and keeping him under constant surveillance. This activity was referred to as "rough shadowing", surveillance so deliberately open and obvious that anyone could be aware of it. In that case, such behaviour was held to be actionable: ${ }^{95}$

... rough and open shadowing as here described and defined is an unlawful act resulting

in legal injury to the reputation of the person who is the object of such attentions.

Here, there was no requirement that the behaviour of the defendants should result in some physical injury to the plaintiff, thus making the cause of action somewhat less restrictive than that outlined in Wilkinson v. Downton. ${ }^{96}$ It would not, however, seem too far-fetched to suggest that a Canadian court, faced with similarly excessive behaviour, would find the reasoning of the American court in Schultz to be persuasive.

The principle enunciated in Wilkinson is likely broad enough to cover most cases where there is actual contact between the investigator and the subject under investigation, and where false information is given to the subject in such a manner as to induce some physical harm through emotional distress. In Wilkinson, the defendant was a mere practical joker who had no clear malicious intent, so malice would not be necessary to found an action. It is contended that, were a court faced with extreme behaviour by an investigator which resulted in severe distress to a plaintiff, but no clear physical harm, the court would be able to extend the principles in Wilkinson to allow for recovery. The current trend in tort law seems to differentiate very little between severe emotional distress and physical injury. The dividing line is very difficult to find. It may be, however, that the courts will show themselves reluctant to abandon the requirement for physical harm, and it has been argued that they show no such intention. ${ }^{97}$

94. Supra, n. 42.

95. Id. at 390.

96. Supra, n. 91.

97. See P. Burns, "Privacy and the Common Law: A Tangled Skein Unravelling?" in Aspects of Privacy Law, supra, n. 81 at 21. 


\section{NUISANCE}

Most private investigators do not engage in behaviour outrageous enough to bring into play the principles of Wilkinson, nor do they habitually break into people's houses so as to attract the attention of the police. Surveillance techniques are usually subtle, so as not to allow the subject to realize that he is under surveillance. However, one may become aware of such surveillance, either while it is in progress or some time afterwards. A possible remedy exists in nuisance to prevent surveillance activity which disturbs an individual in the occupation of his property. Being watched and photographed in what one assumed was the privacy of one's back yard would appear to be such a disturbance.

However, nuisance requires damage, and mere annoyance is probably not enough. There must be inconvenience at least materially interfering with ordinary comfort..$^{98}$ If the conduct complained of is directed solely towards annoyance, it may be actionable ${ }^{\infty}$ but this would be the case only where the conduct is unreasonable. It would be difficult to win a case where the defendant could prove a legitimate interest in the conduct. Motivation is, therefore, important in determining whether behaviour is unreasonable. But as Fleming points out, ${ }^{100}$ dicta in Victoria Park Racing Co. v. Taylor ${ }^{101}$ supports the right to overlook another's property regardless of motivation or purpose. In that case, a racing tout erected a platform outside the plaintiff's property for the purpose of broadcasting racing results. The plaintiffs complained that this was causing them financial loss, and was an invasion of their privacy. The court held that there was no general right to privacy ${ }^{102}$ and the defendant's actions could not be restrained. Thus, it can be seen that an attempt to restrain an investigator from watching a plaintiff from outside his property might be a difficult action to maintain.

Furthermore, there is also Canadian authority to the effect that there is no common law right to prevent watching from outside the property. In $R e$ Copeland ${ }^{103}$ Grant J. of the Ontario High Court, said: ${ }^{104}$

Ancient authority is to be found for the proposition that in English law the natural rights of an occupier do not include freedom from view and inspection by neighbouring occupiers. ... if the defendant commits an annoyance by watching or listening from the other side of the road there is, normally, no protection that the occupier can have under the civil law.

One case which seems to contradict this apparent right to watch another is the Ontario case of Poole v. Ragen. ${ }^{\text {10s }}$ The plaintiffs in that case sought an injunction to prevent the Toronto Harbour Police from continuing to follow them and interfere with their right of navigation in the Toronto

98. Fleming, supra n. 1, at 388.

99. Id.

100. Id. at 574-75.

101. (1937) 58 C.L.R. 479 (Aust. H.C.).

102. Id. at 496.

103. (1972) 28 D.L.R. (3d) 26.

104. Id. at 36.

105. [1958] O.W.N. 77 (Ont. H.C.). 
Harbour. The defendants claimed they were doing this ony to catch the plaintiffs violating a city bylaw. No real evidence as to this violation existed. The case, unfortunately, omits the actual details of the surveillance. However, the surveillance was held to be sufficiently serious to result in $\$ 2,000.00$ punitive damages (in 1957) "as an indication of my disapproval of the Habour Police in this case". ${ }^{106}$ This is unfortunate as the details would have given us some indication of how serious such a surveillance must be to incur judicial interference.

It is obvious that the Harbour Police went beyond mere watching or following at a distance. ${ }^{107}$

.. the conduct of the Harbour Police was something more than mere personal inconvenience and interference with enjoyment of one's quiet and one's personal freedom or anything that discomposes or injuriously affects the senses or the nerves. . . . I think it would be an affront to the dignity of any man or woman and ... is an actionable nuisance.

The judge held that the action was a "serious interference with the plaintiffs' rights", ${ }^{108}$ and, furthermore, that there was no indication that the defendants planned to stop (". . . the police order stands unrevoked that the plaintiffs' vessel should be followed closely. . . ."') $)^{109}$ and so the injunction issued. Certainly if an injunction is available against overzealous police officers, it is submitted it would also be available against a private investigator. The extent of the nuisance would have to be quite great in such a case because it is a public nuisance to interfere with an individual's right to unimpeded passage through a public waterway. For an individual to sue, he must prove special and greater damages above and beyond those of the ordinary public. There seems, however, no logical reason why this case should not apply equally to interference with passage along public roadways, ${ }^{110}$ a situation far more likely to occur. An investigator who followed a vehicle too closely or who interfered with safe driving on more than one occasion could possibly be restrained by an injunction to prevent the continuation of the nuisance.

The Alberta Court of Appeal decision in Motherwell v. Motherwell '"' raises the interesting possibility of an expansion of the tort of nuisance to cover another variety of invasion of privacy. In that case the defendant made numerous hysterical and harassing telephone calls to her father and brother over the course of a number of years. The calls all involved accusations against the housekeeper and against the brother's wife. The result was that the plaintiffs became afraid to answer the telephone, and their home and business lives suffered. Damages were awarded against the defendant and an injunction issued to prevent her from continuing to call.

106. Id. at 79.

107. Id. at 77.

108. Id. at 79.

109. Id.

110. See H. Rowan, "Privacy and the Law" in New Developments in the Law of Torts, Law Society of Upper Canada Special Lectures (1973) 259 at 267-8.

111. [1976] 6 W.W.R. 550. 
The most thought-provoking part of the case occurred in the judgment of Mr. Justice Clement where he laid out the basis upon which he felt a court justified in creating a new category of law. A legal principle, he argued, is a general concept of rights and duties and a legal category merely the application of that principle to particular circumstances. Where facts do not bring a case into existing categories, one looks to the principle to discover whether the case is one where the principle clearly applies. If so, the creation of a new category is warranted.

The court, therefore, felt justified in creating the tort of nuisance based on invasion of privacy. This tort requires no physical intrusion to be actionable. This might well cover the making of telephone calls to a plaintiff, but it might not cover surveillance activities. The case seems to indicate that there are grounds for distinguishing the case of telephone harassment from other forms of invasion of privacy: ${ }^{112}$

The matters of complaint are unwanted communications made to the respondents. If such acts are properly within the concept of "invasion of privacy" they occupy a niche of their own, distinct from such matters as surveillance, the clandestine gathering and use of personal information by various means. [emphasis added]

Clement J. refers to the new category of nuisance as "invasion of privacy by abuse of the telephone system", ${ }^{113}$ thus making it appear that it is confined to that means alone. But he also gave judicial approval to the statement that "the category of nuisances ... will never be closed". ${ }^{114}$ This may open the door for nuisances by way of invasion of privacy to be established in other ways. It is submitted that the analogy to picketing, which Clement J. used himself to demonstrate the openness of the tort of nuisance, could be used to support an action in nuisance by way of invasion of privacy for over-zealous surveillance activity.

A different issue might arise if the surveillance takes place outside a subject's place of business. If the surveillance is such that it interferes with the business, or becomes generally known to patrons, there may be an action. Again, the picketing analogy might be sufficient to establish liability for nuisance.

\section{DEFAMATION}

An investigator may be liable for defamation if he publishes untrue statements at any time during the course of, or subsequent to, an investigation. A defamatory statement is one which tends to lower a person in the estimation of others by making them think less of him. ${ }^{115}$ A private investigator could easily find himself in a possible defamatory situation, either as the originator of the statement or as the individual passing it on. The very nature of the investigator's business leads to the obtaining of possibly damaging information, and the mere undertaking of an inquiry can raise imputations of wrongful conduct. An investigator is very likely to

112. Id. at 555 .

113. Id. at 565 .

114. Id. at 566 .

115. See Fleming, supra, n. 1, at 501. 
come into contact with people who are more than willing to make untruthful statements about others, or statements tainted with a disregard for accuracy.

In the absence of a privilege, no one avoids liability for defamation because they honestly believed the statement to be true. Passing on defamatory information even while believing it to be accurate can also be a source of liability. Actual truth is, of course, a complete defence and one which may be employed frequently.

What an investigator needs to avoid is a situation where he states or implies wrongdoing in a subject with no sure knowledge that his statements are true. If the statement is published to a third party, it will be actionable if the facts turn out to be false. In Alberta, the Defamation Act ${ }^{116}$ provides that there is no difference between libel (written defamation) and slander (oral defamation), and that both are actionable without proof of any special damages. In provinces that retain the difference between libel and slander, mere publication of slander in the absence of any special damages will not suffice to found an action. This is true save in four cases where slander is actionable per se, ${ }^{117}$ so that damages are presumed. Several of those categories might be directly applicable to the investigator. Imputation of the commission of a crime is actionable per se and so the investigation of a suspected fraud or theft would have to be dealt with carefully so as to avoid alleging guilt against a subject in the absence of any actual proof. Slandering an individual in relation to his fitness for his profession is also actionable per se. Any employment related investigation would require equal caution so as to avoid the possibility of injuring an individual's professional reputation.

Defamation can be committed by innuendo as well as by direct allegation. In the ordinary sense, innuendo includes all reasonable interferences which can be drawn from words, but in the technical sense, innuendo means words which bear a special meaning not on their face defamatory, but understood as such because of special circumstances. ${ }^{118}$ Thus an investigator needs to be cautious with respect to hints or leading statements which will convey a definite impression on either all, or part of a select audience. In the words of Lord Devlin: "[L]oose talk about suspicion can very easily convey the impression that it is a suspicion that is well founded." 19

Statements made to the investigator's client, in either written or verbal form, may possibly be protected by qualified privilege. Qualified privilege exists when one party is under a duty, legal, social or moral, to make the disclosure to another person, and the other has a corresponding duty or interest to receive the information..$^{120}$ There are no cases as to whether a

116. R.S.A. 1980 c. D-6, s. 1.

117. See Fleming, supra $\mathrm{n} .1$, at $522 \mathrm{ff}$. The four categories are imputation of a crime, of a loathsome disease, of unchastity in a woman or of unfitness for a trade or profession.

118. See A. Linden, Canedian Tort Law (1988) at 634.

119. Lewis v. Daily Telegraph [1964] A.C. 234.

120. Adam v. Ward [1917] A.C. 309 at 334. 
qualified privilege exists as between private investigators and their clients but it is submitted that it is a relationship that should be protected. The confidential nature of their employment and the restrictions placed on them by legislation to prevent the disclosure of information obtained during the course of that employment both support a case for treating the relationship as one where the investigator is under a duty to disclose information to his client. Although one case stated that a stranger cannot claim privilege for his disclosures to a wife about the morals of her husband, notwithstanding her legitimate interest in the matter, the stranger was not hired specifically to make those inquiries as an investigator would be, but was merely an officious busybody. ${ }^{121}$ Where a legal or contractual arrangement exists between an investigator and client in a similar situation, the wife's legitimate interest would then surely give rise to a legal privilege for an investigator respecting his communications with his client.

This is submitted notwithstanding the decision of the Privy Council in Macintosh v. Dun ${ }^{122}$ where a credit gathering agency was denied a qualified privilege primarily on the grounds that they operated their business for profit and it was not in the public interest to protect those who trade for profit in the characters of other people. ${ }^{123}$ The Alberta courts have confirmed this reasoning saying that the mere fact that credit bureaus perform a useful service is no reason for individuals to sacrifice their own reputations. ${ }^{124}$ However, responding to the specific inquiry of one individual, it is submitted, would make the credit agency analogy inapplicable to the investigator's situation, as it is not the routine business of an investigator to trade in people's characters.

If a qualified privilege does exist, then publication of a defamatory statement will be protected to the extent that it is legitimately made and not actuated by any malice. Here, absence of belief as to the truth of the statement could make it malicious and thus the privilege will be forfeited. A reckless statement is as culpable as a deliberate lie. If an investigator were to make a malicious statement on an occasion of privilege to his client, not only will he be liable for the defamation, but so too will the client. By the principle of respondeat superior the principal can be made liable for the defamatory statements of his agent. ${ }^{125}$ The reverse is not necessarily the case. An agent or subordinate who passes on defamatory statements when he is himself innocent of any malice or wrongdoing may still be able to claim the privilege. ${ }^{126}$

There is also some argument to be made that where an investigator acts on behalf of a solicitor with respect to actual or pending litigation, he may be protected by an absolute privilege. The solicitor client privilege; ${ }^{127}$

... extends to statements by potential witnesses to persons engaged professionally in preparing evidence to be presented in court, and to reports upon which their testimony is based.

121. Watt v. Longsdon [1930] 1 K.B. 130.

122. [1908] A.C. 390 (P.C.).

123. Id. at 400 .

124. Gillett v. Nissen Volkwagen [1975] 3 W.W.R. 520 (Alta. S.C.).

125. Egger v. Chelmsford [1965] 1 Q.B. 248; see also Fleming, supra n. 1, at 552.

126. Id.

127. See Linden, supra, n. 118, at 651 . 
Arguably this would include the investigator as well, provided he did not exceed the scope of the directions given him by the solicitor engaging him. It is unlikely that any such privilege could attach to a report made at an earlier date which only later was used as evidence in some judicial process.

\section{E. BREACH OF CONFIDENCE}

In $R$. v. Offley, ${ }^{128}$ an investigator was charged with theft of confidential information after he solicited information from a police of ficer, asking the officer to check names for him from the Canadian Police Information Centre, a data bank used by law enforcement agencies. He was convicted, but upon appeal, the Alberta Court of Appeal ruled that, under s. 283(1) (now s. 322(1)) of the Criminal Code, confidential information was incapable of being stolen. That section reads:

s. 283. (1) Everyone commits theft who fraudulently and without colour of right takes, or fraudulently and without colour of right converts to his use or to the use of another person, anything whether animate or inanimate with intent,

(a) to deprive, temporarily or absolutely, the owner of it or a person who has a special property or interest in it, of the thing or of his property or interest in it.

Information was held to be intrinsically incapable of being "anything" for the purposes of that section. ${ }^{129}$

In an earlier case in Ontario, the court convicted a man of theft of confidential information when he obtained names of hotel employees from personnel and payroll lists in the course of attempting to organize the hotel workers. The Ontario Court of Appeal in $R$. v. Stewart ${ }^{130}$ held that s. 283 was wide enough to protect confidential information from those attempting to misappropriate it. The Supreme Court of Canada, overturned this decision. ${ }^{131}$ Mr. Justice Lamer adopted the reasoning of the Alberta Court of Appeal in Offley, ${ }^{132}$ and ruled that to be considered property under s. 283 , the "thing" had to be capable of being taken away or converted in some manner so as to deprive the victim. No loss or deprivation could be shown and, therefore, there had not been theft. Lamer J. was also concerned with the difficulties which could arise from a contrary ruling considering that it would be impractical to allow information to become property for the purposes of the Criminal Code. The protection afforded confidential information in the civil law was another matter as, according to Lamer J., it arises not from a proprietary interest but rather from some obligation of good faith. ${ }^{133}$

While the criminal law does not protect against the unauthorized "taking" of confidential information, the tort of breach of confidence does. There are those who look to breach of confidence as the form of action most likely to allow the development of a generalized action for invasion of privacy. As breach of confidence presently stands, however, it grants its protection to only some categories of privacy.

128. (1986) 28 C.C.C. (3d) 1.

129. Id.

130. (1983) 42 O.R. (2d) 225.

131. (1988) 50 D.L.R. (4th) 1 .

132. Supra, n. 128.

133. Supra, n. 131 at 10. 
One of the first and most important of breach of confidence cases involving a privacy element was Prince Albert v. Strange. ${ }^{134}$ In that case, the Prince Consort sought an injunction to prevent the publication of certain drawings he and Queen Victoria had prepared for their own private entertainment. He further sought to prevent publication of a catalogue listing the drawings and etchings. He was successful on the grounds that the publisher had obtained the information through a breach of confidence on the part of an employee of a private printing firm. The case has been used to argue that the English courts recognize a right to keep one's private matters private and not to allow others to expose them to the world. ${ }^{135}$ Others have argued that it protects another aspect of privacy altogether and has no place as a case upon which to found an entire area of invasion of privacy. ${ }^{136}$

In any event, the action of breach of confidence has been used to protect privacy interests of some types, and prevent the use or disclosure of confidential information. Breach of confidence can occur in either a contractual or a non-contractual situation. The basic element is that when one person has received information in confidence, or knows that it was originally supplied in a situation of confidence, he is not permitted to pass that information on in the absence of just cause or excuse. ${ }^{137}$ An action will lie for unauthorized disclosures. The truth or falsity of the material, or the motives of the person divulging it are apparently irrelevant to the establishment of liability.

In Duchess of Argyll v. Duke of Argyll, ${ }^{138}$ the Duchess sued her exhusband to prevent him from disclosing information relating to her personal affairs or conduct during the course of their marriage. She was successful in restraining not only him, but also all persons who received their information from the Duke. The court held that certain kinds of information, when received, are received in confidence and ought not to be disclosed. This case has given the greatest support to the protection of privacy interests under the heading of breach of confidence. Even when limiting the application of the case to its facts, it should operate so as to prevent disclosure by spouses or ex-spouses of personal information received by them during the course of the marriage.

H.J. Glasbeek has argued that the case is a singular one, the decision deriving not so much from legal principles as from a peculiarly English distaste for public revelations concerning the private lives of eminent members of the English aristocracy. ${ }^{139} \mathrm{He}$ points out that in another similar case, ${ }^{100}$ two English popular singers were unable to restrain publication of other private information disclosed in confidence, since the court held that

134. [1849] 64 E.R. 293.

135. L.D. Brandeis and S.I. Warren, "The Right to Privacy", (1890) 4 Harv. L. Rev. 193.

136. H.J. Glasbeek, "Limitations on the Action of Breach of Confidence", in Aspects of Privacy Law, supra, n. 81 at 217.

137. Seagerv. Copydex [1967] 2 All E.R. 415 at 417.

138. [1967] Ch. 302.

139. Supra, n. 136 at 261.

140. Id. at 268. The case is Woodward v. Hutchins [1977] 2 All E.R. 751 (C.A.). 
their careers were such that they sought publicity and they could not be heard to complain upon receiving it.

It may be that $\mathrm{Argy} / \mathrm{l}$ protects no more than the marriage relationship, in which case it may have a valuable, but limited use. If the prohibition on the publication of potentially embarrassing and humiliating personal facts cannot be extended beyond this, then there is little reason to see privacy interests being protected per se.

Slavutych v. Baker ${ }^{141}$ is a well known Canadian case relating to a claim of privilege for confidential information in the employment setting. The plaintiff provided an opinion on a colleague who was applying for tenure. He had been told that his opinion was being solicited in confidence, but the tenure form he completed was later used against him as the basis for a charge of misconduct. In the Supreme Court of Canada, Spence J. adopted the reasoning of Sinclair J.A. of the Alberta Court of Appeal, who stated: ${ }^{142}$

... confidential communications, made in good faith, ought not to be used to the prejudice of their maker as a member of the university community.

Glasbeek again argues against seeing this case as one truly protecting the privacy of one's thoughts and opinions..$^{143}$ Rather, he feels, it is one where the court used the breach of confidence terminology to arrive at the decision they sought. He suggests it was the court's distaste for what were basically entrapment techniques which led to the decision. It does not seem likely that the case will allow for protection of every private opinion communicated to another, but perhaps only those where a sense of fair play seems to dictate that the confidence ought to be respected. Courts tend to be far more protective of confidences that arise in the context of certain relationships that have, in and of themselves, an accepted social value; these include marriage, employment, and, in one Alberta case, a relationship between a doctor and the family of a patient. In D.M. v. Lindsay, ${ }^{144}$ the court suggested that a wife might have a right to an injunction to prevent disclosure of information given by her to her husband's doctor as the relationship was such that confidentiality should be fostered. This right could supercede the husband's right to see his medical file. The matter was not decided as the party attempting to prevent the husband from seeing his file at that time was the hospital, and the court said that the right to prevent disclosure was not theirs.

The cases dealing with breach of confidence in other than a business relationship, where some economic interest is at stake, are confined to the granting of injunctions, or to preventing the confidential material from being used in other ways. Cases do not seem to have arisen where any compensation is given for damage already done by the publication of

141. (1975) 55 D.L.R. (3d) 224.

142. (1974) 41 D.L.R. (3d) 71 at 81 .

143. Supra, n. 136 at 262.

144. (1981) 26 A.R. 159 (C.A.). 
truthful, confidential material. In Bingo Enterprises v. Plaxton, ${ }^{145}$ the Manitoba Court of Appeal stated:146

Anticipatory breaches may be restrained, but actual non-contractual breaches are not compensable in the absence of loss of profit.

The majority of successful breach of confidence cases involve some economic element which would not normally operate in the case of private investigators, patent infringements, industrial spying, divulging of trade secrets and the like. If an investigator were to become involved in this area, it is substantially more likely that he would play a preventative role rather than finding himself in the situation of risking an action for breach of confidence. If, however, he did receive confidential information damaging to another's economic interests, the tort is well developed in this area and liability would follow, whether or not he was the individual in whom the confidence was reposed. It may be that it is not a true privacy right that is being protected here, but rather a proprietory one or even the relationship itself. However, this removes us from the subject of protection of privacy perse.

\section{INVASION OF PRIVACY - THE AMERICAN CASES}

American law has long recognized a common law right to privacy and a corresponding common law tort of invasion of privacy. In the main, British, Canadian, and other common law courts have not done so, perhaps under the lingering influence of Victoria Park. ${ }^{147}$ American case law is extensive on the issue of the invasion of privacy by private investigators. These cases are instructive as to precisely what right is being protected. Furthermore, they highlight some of the more unacceptable practices which some private investigators are wont to indulge in. Such activity may not always be confined to the United States, and it is not out of the question that the issues raised in the American cases could be before Canadian courts in the future.

The right to privacy exists in all aspects of an individual's life and is not confined to his home or place of business. There may be occasions when the right is partially or totally waived. For example, the filing of an injury claim with an insurer is held to be a partial waiver of the right to privacy. As long as the subsequent investigation is reasonable, there can be no right of action against the investigator. Furthermore, when one is in a public setting, there may be what amounts to a total waiver of the right to privacy. In Gill v. Hearst Publishing Co ${ }^{148}$ the plaintiffs complained of an invasion of privacy when a photograph of them in an affectionate pose was published. The court held that there was no invasion of privacy as the

145. (1986) 26 D.L.R. (4th) 604.

146. Id. at 614.

147. Supra, n. 101.

148. (1953) 253 P. 2d 441 (Calif. S.C.). 
couple had "voluntarily exposed themselves to public gaze". ${ }^{149}$ Their pose had become, ${ }^{130}$

... part of the public domain. ... In short, the photograph did not disclose anything which until then had been private, but rather only extended knowledge of the particular incident to a somewhat larger public than had actually witnessed it at the time of occurrence.

Therefore, where a plaintiff is in a public place, what he does is public property to a large extent, and photographing or otherwise recording it may not be actionable. The investigator is merely transmitting to a larger public voluntary aspects of a plaintiff's behaviour. This would be true only where the plaintiff has not been induced into participating in the behaviour by the investigator. By analogy, this might also include the reporting of overheard conversations where the level of conversation is high enough to be heard by any surrounding person. It does not, however, apply to genuine eavesdropping.

Cases where an investigator has deliberately set up the plaintiff have been held to be invasions of privacy. In Unruh v. Truck Insurance Exchange, ${ }^{151}$ the investigator befriended the plaintiff who had been injured at work and had undergone four spinal operations. He induced her to go to Disneyland with him where she engaged in behaviour resulting in further injury to her back. Other investigators filmed her behaviour for use against her. The actions of the investigator were held not only to be invasions of privacy but to create liability for the subsequent worsening of her injury. It has been suggested that this type of behaviour is the equivalent of entrapment. ${ }^{152}$

Very rarely does a case turn on one single aspect of behaviour on the part of the investigator. Normally the entire tone of the investigation is in issue. In Pinkerton National Detective Agency Inc. v. Stevens ${ }^{153}$ the entire surveillance was held to be excessive. Investigation included shadowing, night surveillance, eavesdropping, trespassing and misrepresentation. The surveillance was also conducted over an unreasonably long period of time. In addition the court held the investigation to be malicious in nature. ${ }^{154}$ Where investigators conduct an investigation in such a way as to be offensive and intimidating to the subject there will be liability: ${ }^{\text {ss }}$

Courts have stated that a reasonable investigation is one that is conducted within the limits of decency, is unobtrusive, is limited and calculated to obtain defense information, occurs over a reasonable period of time (several days rather than months), is conducted in public, and generally is non-of fensive to persons of ordinary sensibilities.

In Souder v. Pendleton Detectives, ${ }^{156}$ the defendants entered onto the plaintiff's property, peered into her windows, eavesdropped on conversations within the house and followed her about openly. The court held this

149. Id. at 444.

150. Id. at 445 .

151. (1972) 498 P. 2d 1063 (Calf. Sup. Ct.).

152. See LaMarca, supra, n. 56 at 608.

153. (1963) 132 S.E. 2 d 119 (Ga. Ct. App.).

154. Id. at 122-25.

155. See LaMarca, supra, n. 56 at 604-605.

156. Supra, n. 59. 
behaviour to be unreasonable and beyond the bounds of decency. In Forster v. Manchester, ${ }^{137}$ on the other hand, the court held that the surveillance had been reasonable as there was no use of improper techniques, no spying or trespassing on private property, no close following and no demonstrable intention to cause distress. These two cases read together form the basis of much of the current American law on defining a reasonable surveillance.

\section{INVASION OF PRIVACY IN CANADA}

Until very recently there was no case in Canada where a right to privacy had been recognized and afforded judicial protection by way of a common law action for invasion of privacy. In Quebec, the 1957 case of Robbins v. C.B.C. ${ }^{138}$ established that an action for invasion of privacy could be maintained in that province under Art. 1053 of the Civil Code. That article reads: 159

1053. Every person capable of discerning right from wrong is responsible for the damage caused by his fault to another whether by positive act, imprudence, neglect or want of skill.

The common law proved to be somewhat more inflexible than the civil law in this area.

In Krouse v. Chrysler Canada, ${ }^{160}$ the court declined to strike out a claim for invasion of privacy on the grounds that it disclosed no cause of action. In an oft-quoted statement the Ontario court said: ${ }^{161}$

It may be that the action is novel, but it has not been shown to me that the court in this jurisdiction would not recognize a right to privacy.

The question of an invasion of privacy was never decided in that case, but a number of other cases were subsequently heard in Ontario, all of which endorsed the view of the court in Krouse, that the right to privacy had not been shown not to exist. ${ }^{162}$

These cases all dealt with one particular aspect of invasion of privacy, appropriation of personality, where an individual complains that his name, face or some other attribute is being exploited without his consent. However, an exception was the case of Capan v. Capan, ${ }^{163}$ which involved telephone harassment, and a claim for nuisance by way of invasion of privacy. The Ontario court cited Motherwell ${ }^{164}$ in support of the existence of such a cause of action and refused to strike out the plaintiff's claim. The court had the right to hear the action and decide whether such an action could be successfully maintained in Ontario.

157. Supra, n. 56.

158. (1957) 12 D.L.R. (2d) 35.

159. Art. 1053. C.C.Q.

160. [1970] 3 O.R. 135 (Ont. H.C.).

161. Id. at 136.

162. Athans v. Canadian Adventure Camps Ltd. (1977) 17 O.R. (2d) 425; (H.C.) Heath v. WeistBarron School of T.V. (1981) 18 C.C.L.T. 129 (Ont. H.C.).; Burnett v. The Queen (1979) 23 O.R. (2d) 109 (H.C.).

163. (1981) 14 C.C.L.T. 191.

164. Supra, n. 111. 
Finally, in 1981, one judge firmly declared invasion of privacy to be a tort at common law. In Saccone v. Orr ${ }^{165}$ the defendant had tape-recorded a private conversation with the plaintiff and had played it back in a public meeting, notwithstanding that the plaintiff had warned him not to. A local newspaper reprinted parts of the tape. This caused the plaintiff considerable embarrassment and he became ill and subsequently lost his job. The plaintiff sued for invasion of privacy, and was awarded damages of $\$ 500$.

Co. Ct. Judge Jacob cited both Motherwell ${ }^{166}$ and Krouse ${ }^{167}$ in support of his decision to allow the action: ${ }^{168}$

Certainly, for want of a better description as to what happened, this is an invasion of privacy, and despite the very able argument of defendant's counsel that no such action exists, I have come to the conclusion that the plaintiff must be given some right of recovery.

In an annotation, John Irvine $\mathrm{e}^{169}$ ponders some of the difficult questions which this case brought to light. Would the tort be actionable per se, or, would damages be required? Is malice necessary to found an action, or, is it irrelevant? Irvine hoped for early clarification and expressed his interest in seeing how the courts would treat this tort in future. Unfortunately, Saccone appears never to have been followed again and Irvine's questions remain unanswered.

Irvine also brought up the point that the development of a common law tort of invasion of privacy would probably not be of interest to those provinces which had a Privacy Act, as presumably all invasions of privacy would fall to be considerd under such a statute. ${ }^{170}$ This might not be as obvious as it seems. In Bingo Enterprises v. Plaxton, ${ }^{171}$ an action was brought for invasion of privacy under the Manitoba Privacy Act, or alternately under the common law. Monnin C.J.M. seems to envisage the possibility of a common law action existing outside of the Privacy Act: ${ }^{172}$

It would appear that at common law the tort of violation of privacy in regard to disclosure of private information has not been recognized in Canada. Neither counsel has supplied us with a case indicating that this tort has been recognized ... This is certainly not a proper or adequate factual situation to develop new law on the tort of invasion of privacy rights at common law.

He then went on to find that there had been no substantial and unreasonable interference with privacy under the Privacy Act. It is interesting to speculate whether circumstances could arise where there could be invasions of privacy actionable under the common law which could not be actionable under the Privacy Act, or vice versa. It should be noted that although this case was decided four years after Saccone, that case would not appear to have been drawn to the attention of the court,

165. Supra, n. 2.

166. Supra, n. 111.

167. Supra, n. 160.

168. Supra, n. 2 at 46.

169. Id. at 38.

170. Id. at 39.

171. Supra, n. 145.

172. Id. at 608 . 
notwithstanding that it dealt with precisely the case Monnin C.J.M. mentioned, that is, disclosure of private information. Apparently, the court gave counsel additional time to file extra material on breach of confidence as an extension of their argument on invasion of privacy, even going to the extent of citing Prince Albert to them, but counsel did not take advantage of this opportunity. ${ }^{173} \mathrm{O}^{\prime}$ Sullivan $\mathrm{J}$.A. was clearly of the opinion that the breach of confidence cases were relevant, and that the Privacy Act was not meant to include within its scope the full range of remedies available in the common law to deal with breach of confidence. ${ }^{174}$

A recent case, $R$. v. Otto, ${ }^{175}$ has raised the issue of the right to privacy under the Charter of Rights and Freedoms. In Otto, a woman was charged under the Statistics Act ${ }^{176}$ with failure to fill out a census form. She pleaded lawful excuse in that the census form was an invasion of privacy. The court decided that the requirement to answer the questions on the long form of the census was an invasion of privacy. Judge Hogarth cited the Supreme Court of Canada case of Hunter v. Southam ${ }^{17}$ wherein the Supreme Court ruled that s. 8 of the Charter of Rights, the protection from unreasonable search and seizure, was founded upon the right to privacy and not upon the laws protecting against trespass. ${ }^{178}$ Motherwell was also cited, again in support of enlarging the categories of law where new facts gave rise to new categories.

The court in Otto held privacy to be a necessary attribute of human existence, and not a gift from the state. The freedoms possessed by Canadians are not conferred upon them by the state or by legislation but exist separately and apart from any state action. This is the interpretation to be put upon s. 26 of the Charter which accepts the existence of other rights not specifically enumerated in the Charter. The right of privacy is one of these. ${ }^{39}$

All freedoms, including the right to privacy, can be limited by reasonable state intervention. Questions in a census form are reasonable if they are necessary in order for the proper functioning of various public bodies. The court concluded that strong evidence was required to prove that the sort of intensely personal questions found on the census form were necessary. No explanation of the necessity of these questions was ever given. Thus there was no demonstrable justification for this invasion of privacy.

If privacy is one of the rights referred to in s. 26 of the Charter of Rights, as Hogarth Co. Ct. J. ruled, does that in fact lend a great deal of weight to an argument that such a right ought to be enforceable by way of civil action? Otto might seem to stand only for the right of Canadians to resist

173. Id. at 612 .

174. Id. at 610.

175. (1984) 16 C.C.C. (3d) 289 (B.C. Co. Ct.).

176. S.C. $1970-71-72$, c. 15.

177. [1984] 11 D.L.R. (4th) 641 (S.C.C.).

178. Id. at 652 .

179. Supra, n. 175 at 305. 
governmental intrusions into their private lives, without compelling justification based on the right to privacy. Judge Hogarth himself obviously felt that the right could be extended from there and, moreover, that it should be: 180

I do not hesitate to suggest equally that in an appropriately obvious case to suggest that if the voyeur, eavesdropper, mail censor or other imprudent inquirer, cannot be restrained by injunction because the court is shackled to crystallized statutory causes of action ... . which ... defy appropriate development and preclude innovation, there is demonstrably a lack of adequate judicial response to an obvious need.

However, Professor Hogg maintains that the correct interpretation of s. 26 of the Charter is that it is: ${ }^{181}$

\footnotetext{
... a cautionary provision, included to make clear that the Charter is not to be construed as taking away any existing undeclared rights or freedoms. . . . Section 26 does not incorporate these rights and freedoms into the Charter or "constitutionalize" them in any way.
}

On this interpretation, the right to privacy then is not constitutionally protected but remains, if it ever was, a common law right subject to repeal or abolishment like any other. More importantly, on Professor Hogg's point of view, it would remain a right to which the enforcement section of the Charter, s. 24, would be inapplicable. ${ }^{182}$

If privacy exists as an unenumerated ground under the Charter of Rights, or if it may be protected under some other sections, most notably Ss. 7 and $8,{ }^{183}$ the question then arises as to whether the Charter could be made applicable to private investigators. Section 32 of the Charter makes it applicable to the Parliament and government of Canada, and to the legislatures and governments of the provinces. Merely because a profession is regulated by way of federal or provincial legislation does not necessarily make the Charter applicable to its members. This alone does not make a profession part of "government." There must be some closer connection.

Since the Supreme Court of Canada's ruling in Retail, Wholesale \& Department Store Union, Local $580 \mathrm{v}$. Dolphin Delivery Ltd. ${ }^{183}$ this issue of the applicability of the Charter to private individuals has been considerably clarified. Mr. Justice McIntyre ruled that, although the Charter applied to the common law, it did not apply to private litigation in the absence of reliance on governmental action or authorization. The Charter applied to the executive, legislative and administrative branches of government, and to the extent that a private action is justified by or depends upon some statutory authority, or upon some other governmental action, then the government authority or action, and thus indirectly the private action is

180. Id. at 304.

181. P. Hogg, Canada Act 1982, Annotated (1982) 70.

182. Id.

183. It is beyond the scope of this paper to enter into an exhaustive survey of the privacy interests which might be protected under ss. 7 and 8 . Certainly some cases have arisen where these sections have been held to protect some aspect of privacy. See: Hunter v. Southam (supra n. 177); R. v. Videoflicks Ltd. (1984) 14 D.L.R. (4th) 10 (Ont. C.A.); R. v. Parmar (1987) 34 C.C.C. (3d) 260 (Ont. H.C.).

183. (1987) 33 D.L.R. (4th) 174. 
subject to the Charter. ${ }^{184}$ Failing that connection, private litigation remains private and the Charter has no application.

Mr. Justice McIntyre stated that: ${ }^{185}$

... it is difficult and probably dangerous to attempt to define with narrow precision that element of governmental intervention which will suffice to permit reliance on the Charter by private litigants in private litigation.

Keeping this in mind, an attempt can be made to analyze whether the private investigator exercises any governmental functions or relies upon some governmental authority.

There is an argument to be made that licensing confers powers upon an investigator that he would not otherwise have, but Canadian legislation is uniformly silent on the question of status or powers for investigators. It is probably a better view that licensing is a limitation on the powers of an investigator rather than otherwise. Failing legislation, there would be no restrictions on the right of an individual to carry on any investigation, no more than any individual is restricted from a casual investigation of one of his friends. Legislation was brought in to control investigators who worked for pay, and not to give them any powers that they did not already possess as private individuals.

The key question to be answered with respect to Charter applicability is whether or not an individual or a body can be said to exercise governmental functions. ${ }^{186}$ Do private investigators exercise governmental functions? They are not peace officers and all provincial legislation attempts to make clear the distinction between police officers and private investigators. As previously pointed out, Alberta legislation contains a specific ban on investigators holding themselves out as police officers or as capable of exercising police functions. ${ }^{187}$ Private investigators act as agents for private parties who require assistance in the investigation or enforcement of some legitimate legal right or right of property. If the Charter can be made applicable to them at all, it could only be in situations where the principal is subject to the Charter. Security guards have, in the United States, been held to operate in a quasi-police setting. On some occasions they have been required to "Mirandize" suspects and to abide by all other rules of proper police procedure.$^{188}$ In one case, this was based on their statutory powers of arrest. ${ }^{189}$ In Canada, a security guard has no greater powers of arrest than any other person, and so this argument is not directly applicable. In any event, the powers of security guards are outside the scope of this paper.

Where a private investigator is hired by a private individual (such as an employer or insurance company) to search for evidence of criminal activity, it could be argued that the investigator could be exercising quasipolice powers. Given the public misconceptions that abound as to the

184. Id. at 195.

185. Id. at 197.

186. See McKinney v. University of Guelph (1988) 63 O.R. (2d) 1 (C.A.) at 14.

187. Private Investigators and Security Guards Act, supra, n. 3, s. 17.

188. See People v. Zelinski (1979) 594 P. $2 d 1000$ (Calif. Sup. Ct.).

189. Lucas v. United States 411 A. $2 \mathrm{~d} 360$ (Wash. D.C. Ct. Ap.). 
status of such an investigator, it is conceivable that the subject of an investigation could feel himself under some compulsion with respect to questioning or providing evidence. Similar feelings could influence the behaviour of others questioned in connection with the investigation. But misconceptions as to status do not confer that status upon the investigator, and in reality, he has no more power than any other person to detain or question a witness. Admittedly, there are consequences to a refusal to cooperate with an investigator that would not apply in the case of a purely personal inquiry, but these are consequences which follow naturally from the investigation itself. If one files a claim for insurance, and then refuses to co-operate with the insurance company to determine one's entitlement to the claim, one can hardly complain when the insurer refuses to pay out. Even where an investigator misrepresents his powers to a subject, the subject has a recourse unavailable to one who is made the subject of a police inquiry. Complaints about the behaviour of the investigator can be made to his principal, or legal assistance sought to prevent abuses. An individual cannot be charged with any offence for a failure to co-operate.

Where an investigator does misrepresent his powers to a subject and, in effect, compels the individual to submit to an examination, there may be remedies outside the Charter to deal with such a situation, for example, an action for false imprisonment or assault. These would not be helpful, however, in a situation where a confession was obtained and criminal charges preferred against an individual on the basis of that confession. Insurance companies have preferred charges of fraud against persons submitting false insurance claims where an investigation has shown the claim to be unjustified. If the sole evidence against the defendant is that of a private investigator who has obtained a confession through the exercise of some pressure, the defence will be concerned to have that confession excluded. Jurisdiction exists in the court to exclude confessions made involuntarily where circumstances show that it would bring the administration of justice into disrepute, resort to the Charter remedy under s. 24(2) need not be necessary to achieve this exclusion. Bringing the Charter into operation to exclude evidence obtained by private investigators would place upon them the burden of requiring Charter warnings to be given prior to any questioning of persons who may be suspected of criminal offences.

Private investigators are clothed with some authority, but it is only the authority of their principal. If the Charter is made applicable to them, it would be an indirect way of making the Charter applicable to the principal. This would be an unacceptable extension of the authority of the Charter where Parliament clearly did not intend it. The mischief the Charter is aimed at preventing is the abuse of the power or authority of the state. Where an investigator possesses no state power to compel co-operation, his position is the same as an ordinary curious bystander's. It has been argued that s. 32 ought not to be read so narrowly as to eliminate its application to private persons, ${ }^{190}$ but these arguments have been dealt with by Dolphin

190. M. Manning, Rights, Freedoms and the Courts (1983) 121. 
Delivery. The only conclusion can be that $\mathrm{s} .32$ is clearly limited and that inclusion ought to be solely on the basis of whether the individual or entity can be seen as "government". The contrary argument that all should be covered by the Charter unless specifically excluded is now incorrect.

Slightly different considerations might apply where an investigator acts as the agent of some government body. The police are usually kept informed of the progress of investigations that show some promise of revealing a criminal offence, or of providing evidence that could be used in the prosecution of a known criminal offence. If an investigator is retained directly by the police to investigate an offence, then his principal is "government" and it might seem appropriate to extend that status to the investigator as well. This would be more persuasive where it is felt that the police were trying to do indirectly what they were prevented from doing directly. On the other hand, if the subject of investigation is unaware of the connection between the investigator and the police, or that the investigator is acting as the agent of some official body, there is arguably no state coercion and the mischief that the Charter is designed to prevent is not occurring.

Here it would be instructive to consider the position of a police informer who provides evidence for the police in return for some type of consideration. The police informer is not obliged to warn those from whom he receives information of their legal rights under the Charter. Using the Dolphin Delivery test, if the investigator possesses no police powers, or invokes no state assistance in the course of his investigation, it is not inconceivable that his actions would have no grounding in governmental authority, even where he is an agent of the police. Thus his behaviour would not be subject to the Charter, nor would he be able to be restrained by section 24 .

Arguably, one situation where the Charter has some application is where an investigator acts on behalf of some other non-police arm of government. In I.C.B.C. v. Somosh ${ }^{19}$ the investigator was hired by the Insurance Corporation of British Columbia, a body created by the British Columbia Legislature. The Act ${ }^{192}$ governing the Corporation states specifically that it is an agent of the Crown, and its entire administration and internal procedure is closely controlled by the Government. The Corporation reports to the provincial legislature through its responsible Minister. If the test for the applicability of s. 32 is the exercise of statutory power and authority, Crown corporations would seem to be government. This would seem more likely to be so in the case of a Corporation exercising a mandatory and monopolistic control over a needed public service, such as automobile insurance. If I.C.B.C. itself were held to be government, and therefore subject to the Charter, ${ }^{193}$ there would seem to be no logical reason why its agent, the private investigator, acting openly as its agent, ought not

191. Supra, n. 53.

192. Insurance Corporation Act, R.S.B.C. 1979, c. 201 , s. 12.

193. As was presumed to be the case in Davidson v. Davidson (1987) 33 D.L.R. (4th) 161 (B.C.C.A.). 
to be subject to the provisions of the Charter as well. There may be some difference between the activities of a Crown Corporation that are directly statutorily authorized and those which are not. It is conceivable, although perhaps unlikely, that in the carrying out of an investigation into an insurance claim, I.C.B.C. (for example) could be thought to be acting as a private entity, while in a matter such as deciding claims liability, where the interpretation of some regulation or portion of the governing legislation is required, they become "government". ${ }^{194}$ It may be worth noting that few insurance companies retain their own investigators for these purposes, and in fact in Somosh, ${ }^{195}$ the investigator retained by I.C.B.C. was not its own employee, but hired specifically for the purpose of that investigation. Thus, it may be held that the employment of investigators is not part of their regular business and therefore divorced from their governmental functions.

In any event, if the Charter is applicable in this type of situation, it would be not only the possible unenumerated right of privacy that would be protected from the investigator, but all the other rights, most importantly those against unlawful search and seizure, arbitrary imprisonment, right to counsel and protection against self-incrimination. To say that this would immensely complicate the task of investigation, particularly of insurance cases, would be to underestimate the impact of such a ruling. There is no way of knowing how the courts would approach this matter. There has been as yet no case where the status of an investigator as agent for some arm of government has been discussed.

Manning is clearly of the opinion that there is substantial reason to find investigators subject to the charter. ${ }^{196} \mathrm{He}$ seems to equate them with police forces, although it is not entirely clear whether he refers to investigators alone, or to investigators together with security guards. Certainly, the position of security guards would appear to be more likely to lead to a finding that the Charter would be applicable in their case. However, an Ontario court recently rejected the notion that security guards are subject to the Charter. In $R$. v. Crawford,${ }^{197}$ the defendant sought to exclude evidence obtained as the result of a search by loss prevention officers of a department store, on the grounds of an illegal search. Fontana Prov. Ct. J. raised the question as to whether a loss prevention officer acted on behalf of the police or the government and concluded that he did not. The officer acted at all times as the agent of his employer, a private entity, and thus there was no question of Charter applicability to his behaviour. ${ }^{198}$

194. This precise point was made by the British Columbia Court of Appeal in Harrison v. University of British Columbia [1988] 2 W.W.R. 688 at 696.

195. Supra, n. 53.

196. Supra, n. 190, at 121.

197. Unreported, June 24, 1988, O.T.O. No. 1276 (Ont. Prov. Ct.).

198. Crawford is quite clearly in opposition to the Alberta Court of Appeal decision in $R$. v. Lerke (1986) 24 C.C.C. (3d) 129, where a search by tavern employees of an underage patron was held to be a violation of the Charter. Lerke was disapproved of by the Ontario Court of Appeal in Re Blainey and the Ontario Minor Hockey Association (1986) 54 O.R. 513 at 522, and furthermore, this disapproval was cited by McIntyre, J. in Dolphin Delivery (supra, n. 183 at 193) as another example of the way in which the Charter was not meant to cover private activity. By virtue of this authority, Fontana, Co. Ct. J. felt justified in reaching a contrary conclusion in Crawford. It may be that Lerke is now doubtful authority. 
This is not, however, a definitive answer to the question of whether either security guards or private investigators can ever be found to be subject to the Charter. Fact situations could arise where Crawford would be distinguishable. Also, neither counsel spoke to the matter during the course of the trial, and so the judge's remarks are clearly obiter. In the absence of any further judicial comment, or guidance from non-Charter cases as to the powers and status of the private investigator, an answer to the question of Charter applicability remains speculative.

\section{THE CANADIAN PRIVACY ACTS}

Three of the Western Provinces and Newfoundland have enacted Privacy Acts which make the invasion of privacy a tort without proof of damage. ${ }^{190}$ British Columbia provided the lead in 1968. The British Columbia Act, like the American common law, does not make privacy an absolute right. Section 1 states: ${ }^{200}$

1. (1) It is a tort, actionable without proof of damage, for a person, wilfully and without a claim of right, to violate the privacy of another.

(2) The nature and degree of privacy to which a person is entitled in a situation or in relation to a matter is that which is reasonable in the circumstances, due regard being given to the lawful interests of others.

(3) In determining whether the act or conduct of a person is a violation of another's privacy, regard shall be given to the nature, incidence and occasion of the act or conduct and to any domestic or other relationship between the parties.

The British Columbia, Saskatchewan and Newfoundland statutes use the word "wilfully" with respect to acts of invasion of privacy requiring, it would seem, intent, and negating the possibility of liability for negligent intrusions. The Manitoba statute, however, extends liability to acts that the defendant "should reasonably have known" would violate privacy. ${ }^{201}$ Thus negligent acts would appear to be included if they are reasonably foreseeable. All provinces make invasion of privacy actionable without proof of damage.

The right protected is circumscribed by the legitimate interests of others, and all of the Acts require those legitimate interests to be taken into consideration. The interesting point here is that the British Columbia, Saskatchewan and Newfoundland statutes require these matters to be taken into consideration in establishing liability, ${ }^{202}$ but in Manitoba these factors are of primary importance in assessing the quantum of damages and not liability per se. ${ }^{203}$ All statutes provide for defences to an action,

199. Privacy Act, R.S.B.C. 1979, c. 336; The Privacy Act, R.S.M. 1987, c. P. 125; The Privacy Act, R.S.S. 1978, c. P. 24; The Privacy Act, S. Nfld., 1981, c. 6. For a detailed discussion and comparison of these acts see P. Osborne, "The Privacy Acts of British Columbia, Manitoba and Saskatchewan" in Aspects of Privacy Law, supra, n. 1 at 73.

200. Supra, n. 199.

201. Supra, n. 199, s. 5(b).

202. Supra, n. 199; B.C. Act, s. 3; Sask. Act, s. 4; Nfld. Act, s. 3(2).

203. Supra, n. 199, s. 5. 
which further clarify the issue of the legitimate interests of others. Again, from the British Columbia Act: ${ }^{204}$

2. (1) An act or conduct is not a violation of privacy where

(a) it is consented to by some person entitled to consent:

(b) the act or conduct was incidental to the exercise of a lawful right of defence of person or property;

(c) the act or conduct was authorized or required by or under a law in force in the Province, by a court or by any process of a court; or

(d) the act or conduct was that of

(i) a peace officer acting in the course of his duty to prevent, discover or apprehend the perpetrators of a crime; or

(ii) a public officer engaged in an investigation in the course of his duty under a law in force in the Province,

and was neither disproportionate to the gravity of the crime or matter subject to investigation nor committed in the course of a trespass.

Manitoba, Newfoundland and Saskatchewan include substantially similar provisions in their Acts. ${ }^{205}$

The Manitoba, Newfoundland and Saskatchewan statutes also refer to specific ways in which a person's privacy may be violated, whereas the British Columbia Act is more vague in this area. From the Manitoba Act:206

3. Without limiting the generality of section 2 , privacy of a person may be violated

(a) by surveillance, auditory or visual, whether or not accomplished by trespass, of that person, his home or other place of residence, or of any vehicle, by any means including eavesdropping, watching, spying, besetting or following; or

(b) by the listening to or recording of a conversation ...

(c) by the unauthorized use of the name...

(d) by the use of his letters, diaries and other personal documents without his consent or without the consent of any person who is in possession of them with his consent.

The Saskatchewan and Newfoundland Acts outline examples of invasion of privacy in a similar way, ${ }^{207}$ but go further and make the occurrence of one of these prima facie evidence of invasion of privacy, thus shifting the burden of proof to the defendant. Osborne, however, in discussing the Saskatchewan Act argues that this is an illusory difference, given that the court is still required to take into account all those matters giving legitimate interest to the defendant. ${ }^{208}$ It is interesting to point out that New Zealand, in an effort to protect against many of these specific invasions of privacy, forbids the filming or recording of any individual without their prior written consent. ${ }^{209}$ This protection is afforded specifically against the conduct of private investigators and may not apply to others.

Newfoundland's statute specifically provides that the rights provided therein are in addition to, and not in substitution for, any other rights possessed by the plaintiff. ${ }^{210}$

204. Supra, n. 199, s. 2.

205. Supra, n. 199; Man. Act, s. 5; Sask. Act, s. 4; Nfld. Act, s. 5.

206. Supra, n. 199, s. 3.

207. Supra, n. 199; Sask. Act, s. 3; Nfld. Act, s. 4.

208. Supra, n. 199, at 106-107.

209. Supra, n. 35, s. 52.

210. Supra, n. 199, s. 7(1). 
In Davis v. McArthur, ${ }^{211}$ the first case to be decided on the B.C. Privacy Act, Tysoe, J.A. stated that "whether there has been a violation of the privacy of another must be decided on the particular facts of each case".212 In this case, a private investigator was hired by a wife to gather evidence of suspected adultery on the part of her husband. The investigator followed the husband to his place of work, observed his activities and placed a locator device on the bumper of the car the husband was driving, in order to find out where he went. The husband later discovered the device.

It appears that the American cases dealing with surveillance and the reasonableness of an investigator's behaviour were not matters which were placed before the court in this case. Certainly two of the leading American cases on the subject were decided and available at the time of the proceedings. ${ }^{213}$ Yet the decision of the court is consistent with those American cases in assessing the overall impact of the investigator's conduct on the subject. The crucial points remain the legitimacy of the investigator's interest and the reasonableness of his conduct: ${ }^{214}$

\begin{abstract}
The appellant was acting as the agent of the wife who had a legitimate interest in her husband's conduct. He was not activated by malice or mere curiosity. It appears to me that throughout he acted with circumspection. His shadowing and observation of the respondent was not conducted in such a way as to attract public attention; nor was it carried out in an offensive manner. In my respectful opinion, it was not so close and continuous as to go beyond reasonable bounds.
\end{abstract}

Several factors were of importance in this finding. The investigator appeared to be discreet in his behaviour. While the surveillance occurred over a long period of time (eight months), it was sporadic during most of that time. The investigator never appeared to have come any closer to the plaintiff's vehicle than three car lengths away. Surveillance was conducted from the street and the investigator never entered onto private property. The attachment of the bugging device was done at the request of the client, the plaintiff's wife, and the device was attached to her car which the plaintiff had borrowed. The court found the defendant to be a normal, healthy man in no greater need of protection from invasion of privacy than anyone else. Tysoe J.A. acknowledged that there might be some who would be entitled to a greater degree of privacy than others (he used the example of a helpless invalid), but this was not the case here. He further acknowledged that knowing that one is being watched would be upsetting to anyone, but that alone is not sufficient to constitute an invasion of privacy. ${ }^{215}$

At trial, an invasion of privacy was found substantially on the grounds that another investigation of the plaintiff was being conducted at about the same time. The identity of the other investigator and the reasons for that investigation were either not known or not disclosed. The trial judge held that as the defendant was aware that he was not the only one following and

211. Supra, n. 47.

212. Id. at 145-146.

213. Souder v. Pendleton, supra n. 59; Forster v. Manchester, supra, n. 56.

214. Supra, n. 47.

215. Id. at 147. 
watching the plaintiff, he ought to have known that a reasonable person would legitimately become apprehensive and emotionally upset in these circumstances. The Court of Appeal, however, declined to follow that reasoning:216

He [the appellant] cannot be made responsible for the results of some following and
watching that occurred at an earlier time, ... While I am prepared to agree that whatever
earlier surveillance took place would be of some consequence in determining whether the
appellant's conduct was reasonable in the circumstances, the trouble is that the evidence
does not disclose the nature and extent of the earlier surveillance.

It would appear then that the investigator's conduct must be taken in context, and that context could include an earlier or simultaneous surveillance, even where that surveillance is being conducted by someone else. But in the absence of evidence relating to the nature and extent of the other surveillance, the investigator is unlikely to be held responsible for the effect that his surveillance produces in conjunction with the other.

In two subsequent cases, actions were brought against B.C.T.V. for publishing photographs and films of plaintiffs and their property, on the ground that this was an invasion of privacy. ${ }^{217}$ Both actions failed, substantially on the ground that anyone could see what was happening on the property and that the events were of public interest. In Silber and Value Industries Ltd. v. B.C.T.V., Lysyk J. quoted extensively from the California case of Gill v. Hearst Publishing, ${ }^{218}$, and expressed approval of the notion from that case that the recording of public activities may not be an actionable invasion of privacy. Public activities include not only activities carried out on public property, but also those carried out on private property when in the full view of the public at all times.

In I.C.B.C. v. Somosh ${ }^{219}$ the private investigator's behaviour was held not to be reasonable. I.C.B.C. brought an action to recover monies paid in settlement of two claims arising from an accident caused by the defendant driver. I.C.B.C. had hired an investigator to determine the defendants' income and assets to determine their ability to pay the claim. The investigator telephoned the male defendant's place of work and asked questions relating to his employment and salary, and also about his character, morals, moods and drinking habits. The investigator also interviewed the female defendant, Mrs. Somosh, in her home and asked her personal questions until she asked him to leave. The court found that there had been an actionable invasion of privacy with respect to the male defendant, but not with respect to the female defendant.

It would seem that the court placed heavy emphasis on the fact that the investigator lacked a legitimate interest in the male defendant, it being decided that there was no cause of action against him. There was no

216. Id. at 145, 146-147.

217. Silber and Value Industries Ltd. v. B.C.T.V., supra, n. 89; Belzberg v. B.C.T.V., supra n. 88.

218. Supra, n. 148.

219. Supra, n. 53. 
attempt to characterize the investigator's behaviour as excessive or offensive: 220

The plaintiff had no legitimate interest in the personal habits of Mr. Somosh and in fact had no claim against him arising out of the accident. That being so, Mr. Somosh is entitled to some damages, even though it appears that no damage resulted from these inquiries.

On the other hand, the behaviour of the investigator with respect to Mrs. Somosh was held not to be an invasion of privacy, notwithstanding that she too was asked personal questions. Those questions were not characterized by the court so it is uncertain whether they also included questions as to her morals and drinking habits. The court specifically denied that the presence or absence of a legitimate interest on the part of the plaintiff was a factor in making the determination with respect to Mrs. Somosh: ${ }^{221}$

I can find no invasion of privacy with respect to Mrs. Somosh on the facts of this case. Whether the plaintiff had a right to investigate her ability to repay the plaintiff is of little consequence in those circumstances. I am simply unable to find evidence to support a claim for any invasion of her privacy.

There are three ways in which one can reconcile the decision to award damages to the male defendant and not to the female. Firstly, there may have been facts not mentioned in the case indicating that the questions asked of Mrs. Somosh were in fact generally non-offensive to a person of ordinary susceptibilities, and thus non-invasive. Secondly, the court may have laid more stress upon legitimacy of interest than it was willing to acknowledge, finding that the plaintiff did in fact have some prima facie case against Mrs. Somosh that entitled them to believe they would be successful at trial. This would give them a legitimate interest in finding out whether she had the ability to pay a judgment against her. Thirdly, the deciding factor could have been that the questions asked of Mrs. Somosh were asked of her in the privacy of her home with no third party present, whereas the questions asked of Mr. Somosh were asked of a third party so that a third party became aware of the action and of the plaintiff's interest in the defendants.

This third explanation seems an attractive one as there is a clear analogy here to the laws of defamation where publication to a third party is a requirement for liability. Personal questions may not be invasions of privacy when directed solely towards the subject under investigation, but where others become involved, there is a greater likelihood that the subject will suffer some embarrassment or humiliation, or have concerns as to his personal security or standing in the community. These matters might well influence a court in deciding whether the invasion of privacy was "reasonable in the circumstances".

It is interesting to note that there was no attempt to raise a defence by use of s. 2(1)(b) of the B.C. Privacy Act, on the basis that the conduct occurred in the course of the exercise of some right of defence of property (the insurance monies claimed byd I.C.B.C.). The insurance monies were certainly the former property of the plaintiff, and an attempt to recover 
them could easily be argued as a defence of property. Many investigations that might otherwise be held invasions of privacy, particularly those in the insurance field, could be held to be authorized under this section if it is read widely enough. ${ }^{222}$ The matter was not however dealt with in Somosh, nor in Davis v. McArthur ${ }^{223}$ (where admittedly there was no ground for such a defence).

In $R$. v. Gibson, ${ }^{24}$ the Saskatchewan Privacy Act was not in issue in the case, since it involved a criminal charge, but the judge made reference to the acts of the accused being evidence of violations of privacy under the Act. The Saskatchewan Act makes reference to certain acts as being prima facie evidence of invasion of privacy: 225

3. Without limiting the generality of section 2 , proof that there has been:

(a) surveillance, auditory or visual, whether or not accomplished by trespass, of a person, by any means including eavesdropping, watching, spying, besetting or following; ...

without the consent, express or implied, of the person or some other person who has the lawful authority to give consent is prima facie evidence of the violation of the privacy of the person first mentioned.

The judge referred to the conduct of the private investigator in Davis $\mathrm{v}$. McArthur and continued: ${ }^{226}$

The accused cannot be spoken of so charitably. He did not act throughout with circumspection. His activities were carried out in an offensive manner. He was no more than a trespasser having obtained consent or permission by misrepresentation. He went well beyond reasonable bounds.

It would seem that if the judge in Gibson had been called upon to decide the matter of an invasion of privacy under the Privacy Act he would certainly have found the defendant liable. In this case the investigator had entered a private dwelling house to collect evidence of adultery. $\mathrm{He}$ had misrepresented himself to the occupants as being an employee of the Saskatchewan Power Corporation, and under that guise, had spent an hour searching the complainant's room in the basement. His entry had been obtained by trespass.

Cases decided under the various Privacy Acts have been rare, notwithstanding that British Columbia's statute has been in force for over two decades. Thus, the amount of guidance they offer with respect to what may be considered an invasion of privacy is limited. However, the following comments can still be made with respect to the private investigator. An investigation which is discreet and unobtrusive will not be an invasion of privacy. Discretion may be shown by minimizing contact with the subject and refraining from any behaviour calculated, or reasonably likely to result in fear or anxiety. Trespassing, while not an invasion of privacy per $s e$, substantially increases the likelihood that other behaviour may be considered to be actionable. Surveillance alone is not actionable; there

222. See Osborne, supra n. 199 at 94.

223. Supra, n. 47.

224. Supra, n. 39.

225. Supra, n. 199, s. 3.

226. Supra n. 39 at 489-490. 
must be other elements present to find an invasion of privacy. Regrettably, no case has dealt with the taking of photographs or films of a subject, and so the propriety of this activity cannot be properly judged. How far can an investigator go in this area? The answer cannot be known at this time although reference can be had to American cases for guidance. In those cases, filming alone is not actionable, although when the subject is in private surroundings, it may be. The two cases involving B.C.T.V. ${ }^{227}$ would appear to stand for the proposition that filming of an individual while on public property, or on private property exposed to the public view, is not normally actionable. The questioning of a subject is not an invasion of privacy, nor is the questioning of third parties necessarily an invasion of the subject's privacy. But when those questions deviate from what is pertinent to the investigation, there may be invasion of privacy.

\section{CONCLUSION}

The subject of invasion of privacy is so new and unexplored that the question of the scope and extent of an investigator's powers must remain for the most part undetermined. Cases dealing with certain torts, such as nuisance and trespass, provide some guidance in answering the question, but will be seen to be largely inadequate when dealing with the special situations created by surveillance activities. Outrageous behaviour is certainly not acceptable, but there are many grey areas where there is simply no guidance at all. For the subject of an unwanted surveillance, the law remains unhelpfully vague in all but the most extreme of cases.

Clearly, the ability to take action based on a generalized tort of invasion of privacy would offer the greatest protection against the unwanted attentions of a private investigator, or the person who has hired him. The existence of such a tort can be recognized either by statute, as has occurred in four provinces, or by the courts, as seen in Saccone v. Orr. ${ }^{28}$ The lack of any judicial comment on Saccone is puzzling. The case, it is submitted, opened the door to the development of an entirely new area of liability, and was founded on some firm and persuasive reasoning of Clement J.A. in Motherwell..$^{229}$ Perhaps, as has been elsewhere suggested, ${ }^{230}$ lawyers remain either unfamiliar with, or cautious of, this area, and so fail to advise clients of the possible remedies available. Perhaps potential plaintiffs are being advised to frame their actions within more acceptable and well recognized heads of liability. But cases under the various Privacy Acts, where liability and remedy provisions are clearly stated, are sparse as well. The reasons for the lack of litigation in this area must remain unclear.

The investigator's position is also unclear. No investigator wants to appear in court to face a criminal charge or a civil action for damages arising out of his activity. Guidance as to appropriate behaviour is hard to

227. Supra, n. 88, n. 89.

228. Supra, n. 2.

229. Supra, n. 111.

230. See Irvine, supra, n. 168. 
find in the existing Canadian case law. In an action for invasion of privacy in particular, an investigator would be well advised to rely on his position as agent, for in the end, he may well stand or fall on the legitimacy of his, and his client's, interest in the subject. The investigator, however, must rely in good faith on his client's accurate assessment of that interest, and if that interest is held by a court to be non-existent, the investigator's reliance in good faith may not exclude him from liability. The investigator is not a legal expert who can evaluate his or her client's case before it comes to court. He must act ethically and discreetly within the boundaries of his client's instructions, and hope that an ex post facto examination of the facts will show him to have acted legitimately.

One other possible solution would be to overhaul the various Acts dealing specifically with private investigators so as to clarify their rights and obligations. As previously mentioned, discussions with respect to amendments have been going on in various jurisdictions for some time. It can be argued, however, that in the attempt to control those investigators who do not adhere to voluntary professional standards of ethics, legislation will also regulate investigators whose behaviour has always remained discreet, and may have the effect of restraining them from properly performing their jobs by placing limits on their access to information or on their use of standard investigative procedures. Investigators who have no great respect for either the criminal or civil law are unlikely to be deterred by regulatory legislation.

The effect of legislative rules on the practice of investigators could in the end be to frustrate the legitimate concerns of clients seeking to protect their own interests. Thus some sort of a balance must be struck between the rights and interests of clients and the right to privacy of those who may become the subject of such investigations. A statutorily created disciplinary body with the power to advise on penalties for violations of professional ethics might provide a mechanism flexible enough to balance these interests. Such a solution, it is submitted, should be considered before taking the more drastic step of specifically legislating prohibited practices.

There is no indication at present that the general behaviour of private investigators in Canada is such as to cause any widespread concern over their intrusions into people's private lives. But such intrusions certainly occur, and a clarification of the respective rights of investigators and subjects in this area is overdue. 